CHARACTERISTICS AND INFLUENCE OF ADVISORY COMMITTEES

$\mathrm{ON}$

PROGRAM PLANNING IN TEXAS SECONDARY AGRICULTURAL PROGRAMS

by

JOSEPH C. BARBOUR, B.S.

A THESIS

IN

\title{
AGRICULTURAL EDUCATION
}

Submitted to the Graduate Faculty

of Texas Tech University in

Partial Fulfillment of

The Requirements for the Degree of

\section{MASTER OF SCIENCE}

Approved

Dr. Scott Burris

Chairman of the Committee

Dr. Jonathan Ulmer

Dr. Steve Fraze

Dr. Lance Kieth

West Texas A\&M University

Dr. Fred Hartmeister

Dean of the Graduate School

August, 2010 
Copyright @ 2010, Joseph C. Barbour 


\section{Acknowledgements}

This work would have never been possible without the help of many individuals in my life who have offered inspiration, motivation and guidance throughout this journey called graduate school. First, I must thank my Lord, Jesus Christ for his guidance throughout my life. I feel as if it was a blessing for me to have even had this opportunity, and it is with his grace that I have worked through it. I would like to thank my wonderful parents for their love and support throughout this process. I would have never made it to this point in my life and education without you. Everything that I have become is because you two have guided me through it. I am thankful beyond description and love you both more than you will ever know. I am proud to have you as my parents. To my family, thank you for support and guidance, I love each and every one of you.

To Dr. Burris, I would like to thank you for your dedication to me throughout this entire process of graduate school, from start to finish. Thank you for the countless hours that you have spent with me over the past 18 months. You have become a true friend. I think I learned more about agricultural education and life sitting in your office than in all my coursework at Texas Tech. Recently, in a job interview, a CTE director asked me,

"What is your definition of a master teacher"? The first thought that came into my head was you. If I can ever in my career become as proficient at educating as you are, I know I will have made it. You are truly a "master teacher" and exemplify this term everyday in your teaching. Your dedication to students truly makes you one of the finest educators I have ever known. 
To Dr. Fraze and Dr. Ulmer, thank you for serving on my committee. Each of you has provided support and guidance that helped make this project a reality for me. I appreciate each of you more than you know. It is because of professors like the both of you that make our department so great. To Dr. Ritz, thank you for allowing me to work with you teaching over the past year, you allowed me to gain valuable skills that I can use for the rest of my career. Good luck on the promotion and tenure process, I know you will do great. To Abby McCulloch, thank you for your friendship and guidance through this thesis process. You helped me many times and I appreciate it more than you will ever know. I know you will make a great teacher and I wish you the best of luck with your career.

To Dr. Kieth, my career choice to become an agricultural educator is because of you. I cannot imagine what I would be doing if you would not have recruited me so many years ago. My passion for agricultural education is only a small testament to what you have instilled in all of us who have graduated from your program. Thank you for the many hours you have spent over the years mentoring me; I appreciate it beyond comprehension. Also, thank you for supporting me through my time at Texas Tech, and serving on my committee. Your support on this project has been greatly appreciated.

My time living in West Texas would not have been great without the support of many friends who have become my family away from home. Gaea Wimmer, Austin Ham, Brian Holladay, Brady Askew, Tyler Hawthorne, Brett Nichols, Jared Satterfield, Kaela Steubing and many more, I hope I can be as good of friend to each of you as you have been to me. Thank you for your love and support. To my fellow graduate students, 
I wish you the best of luck. I know many of you who are working towards careers in agricultural education will all make great professors and teachers. Each of your friendships mean the world to me. 


\section{Table of Contents}

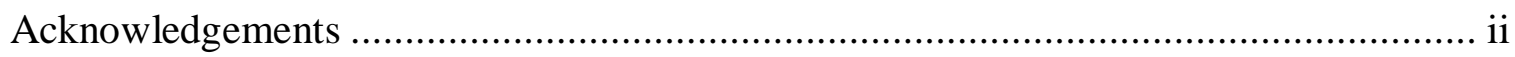

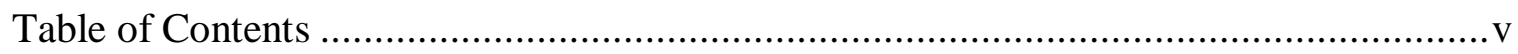

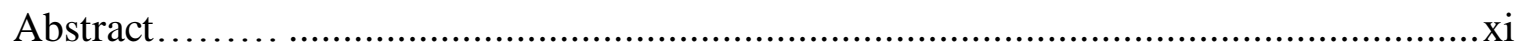

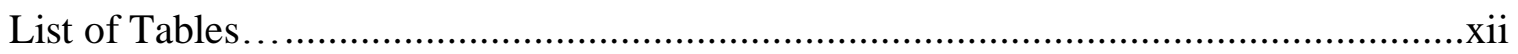

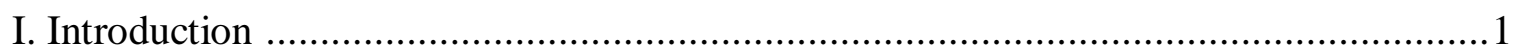

Background and Setting .........................................................................

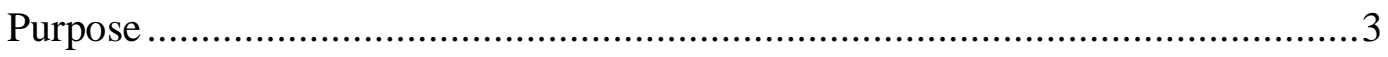

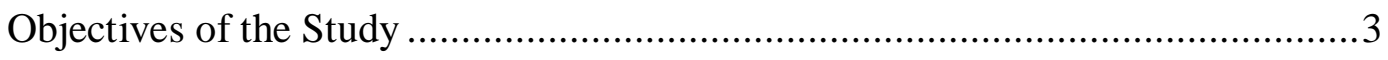

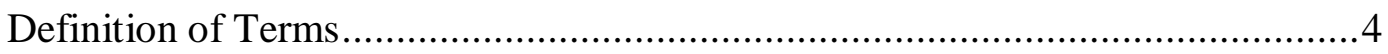

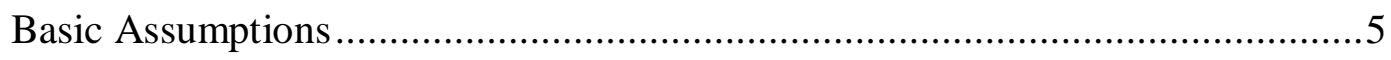

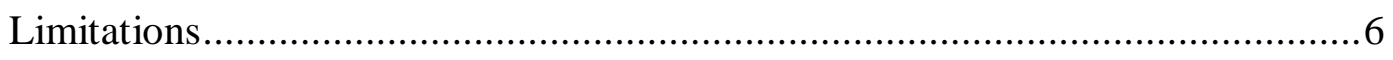

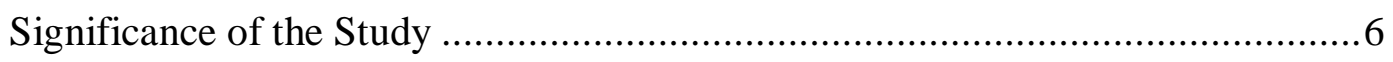

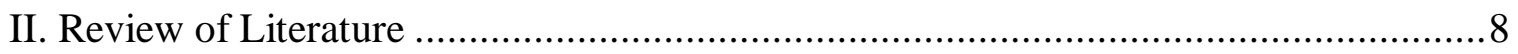

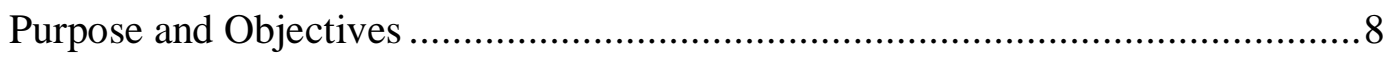

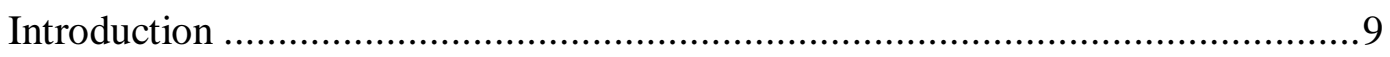

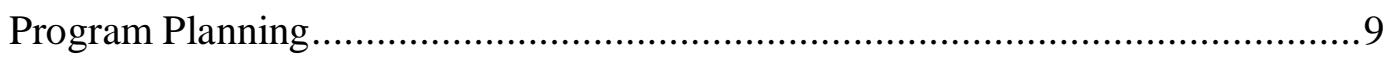


Overview .10

Programmer.

Involvement

Advisory Groups

Surveys .14

Informal Measures. 14

Identification of Problems and Needs .14

Legislation .15

Previous Studies .17

Beginning Agricultural Science Teachers .17

Secondary Agricultural Science 18

Advisory Committees in Extension Education 21

Use of Advisory Committees in Extension Education .21

Views of Advisory Committees in Extension Education .22

Development of Advisory Committee .23

Reference Materials Related to Agricultural Science Advisory Committees .25 vi 
Organization.

Management.

Program Evaluation .

Promotion. 30

Summary

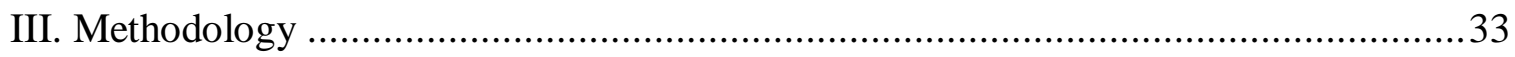

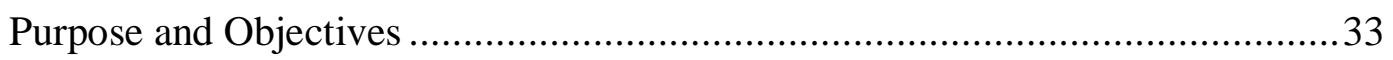

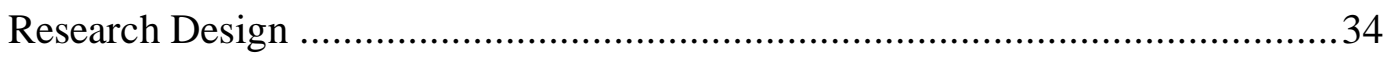

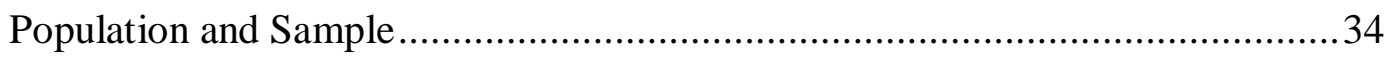

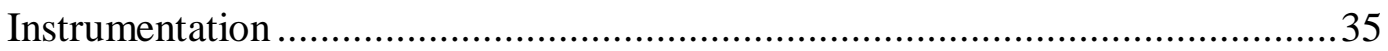

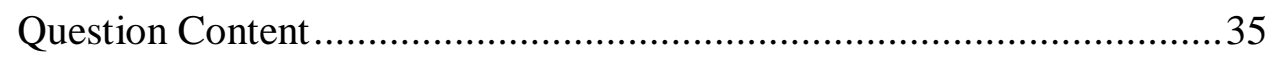

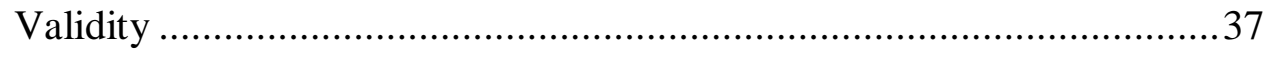

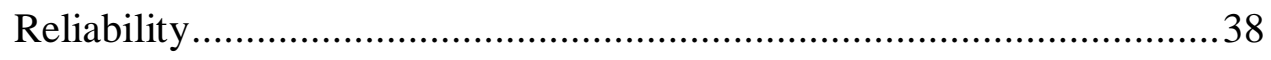

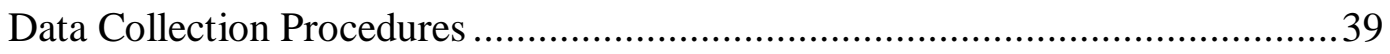

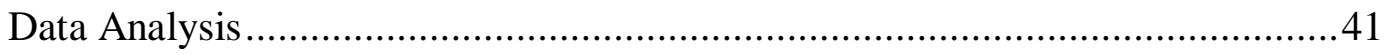

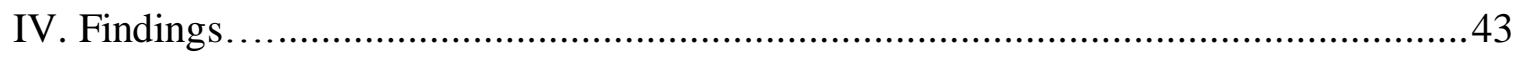

vii 
Purpose and Objectives

Population and Sample 44

Objective One 44

Objective Two .50

Objective Three. .52

Objective Four 62

Objective Five. 65

Objective Six. .66

V. Summary, Conclusions, Implications and Recommendations .70

Purpose and Objectives .70

Limitations .71

Research Design .71

Population and Sample .71

Instrumentation .72

Data Collection Procedures .72

Data Analysis .73

Summary of Findings .73 viii 
Summary of Objective One

Summary of Objective Two.

Summary of Objective Three .76

Summary of Objective Four. .78

Summary of Objective Five. .79

Summary of Objective Six.

Conclusions and Implications

Conclusions from Objective One .81

Implications from Objective One .82

Conclusions from Objective Two .83

Implications from Objective Two .83

Conclusions from Objective Three. .84

Conclusions from Objective Four .86

Implications from Objective Four .86

Conclusions from Objective Five.

Implications from Objective Five

Conclusions from Objective Six

ix 
Recommendations.

Recommendations for Practice

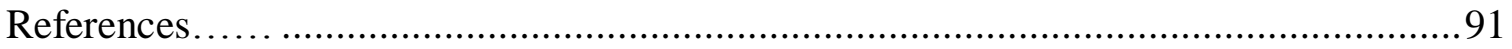

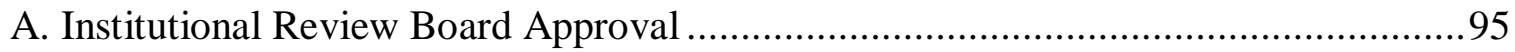

B. Instrumentation 


\begin{abstract}
To be in accordance with state and federal law, secondary agricultural programs must involve parents, academic career and technical (CTE) teachers, administrators, and local business and industry representatives in an annual evaluation of CTE programs. This group is often referred to as an advisory committee. Little in Texas is known as to what extent Texas secondary agricultural programs are currently utilizing advisory committees to annually evaluate CTE programs.

In order to determine what extent advisory committees are being used by secondary agricultural programs, a descriptive study was performed. Data collection took place during the months of January and February 2010 using an online questionnaire developed by researchers at Texas Tech University. The questionnaire was completed by 162 agricultural science teachers in Texas who represent the programs in which they are employed.
\end{abstract}

Findings of this study concluded that agricultural science teachers in Texas believed that the most important functions of an advisory committee was creating a communication link between the program and the community and evaluating the agricultural program. Agricultural teachers who did report utilizing an advisory committee had similar views in regard to the perceived functions of advisory committees on program planning. Overall, most programs in Texas do not currently utilize an advisory committee. The findings of this study have been generalized to include all secondary agricultural programs in Texas. 


\section{List of Tables}

3.1 Participant Contact............................................................ 40

4.1 Students Representing Agricultural Science Programs................................45

4.2 Participation in Activities above the Chapter Level..................................46

4.3 Cumulative Participation above the Chapter Level.....................................47

4.4 Program Agricultural Science Teachers.............................................49

4.5 Perceived Functions of Advisory Committees..........................................51

4.6 Use of Advisory Committees in Texas Reported by Area.............................52

4.7 Use of Advisory Committees in Texas....................................................53

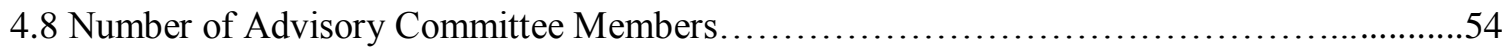

4.9 Attendance of Advisory Committee Meetings.......................................56

4.10 Characteristics of Advisory Committees............................................58

4.11 Identification of New Advisory Committee Members...............................60

4.12 Members Who Have Careers Related to Agriculture...............................61

4.13 Frequency of Advisory Committee Meetings....................................62

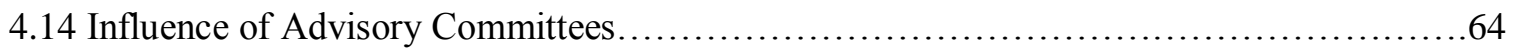

4.15 T-test of Utilization of Advisory Committees

Compared to Non-Utilization...................................................66 
4.16 Relationship between Perceived Functions and

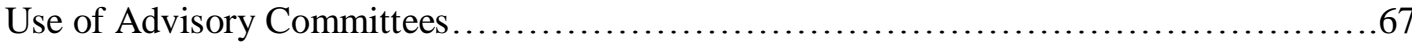

4.17 Influence of Advisory Committees and a Program Characteristic.......................68

4.18 Qualitative Responses.............................................................69 


\section{Chapter I}

\section{Introduction}

\section{Background and Setting}

For almost as long as the United States has had a need for qualified students graduating from secondary agricultural education programs, there has been legislation regulating or pertaining to vocational education itself. The federal role in vocationaltechnical education was clarified with the passage of the Smith-Hughes Act of 1917 (Hayward \& Benson, 1993). The Smith-Hughes Act introduced vocational federal funding to secondary education, impacting career and technical education (CTE) as it is known today.

In 1963, in order to expand federal influence over state CTE programs, the Vocational Education Act of 1963 was passed (Hayward \& Benson, 1993). It was in this legislation where the phrase, "advisory committee" was first introduced in order to periodically review vocational education programs and laws.

The Education Amendments of 1977 is the first mention of advisory committees for vocational education at the secondary level. For the first time, advisory committees were required by federal law for school districts receiving federal funding. The advisory committee's purpose, as stated in legislation, was to provide the school district or agency with current job needs and to provide information regarding relevancy of courses that were currently being offered (Public Law 94-482, 1976).

In 1984, the Carl D. Perkins Vocational Education Act, revised in 1998 and 2006 reemphasized the need for advisory committees by requiring states to take action in their plans to require local vocational programs to evaluate their programs using some form of 
advisory committee. The 2007 Texas State Plan for Career and Technical Education for 2008-2013 responded to the demands of the Carl D. Perkins act by stating in number 6 that:

Texas requires that eligible recipients annually evaluate their Career and Technical Education (CTE) programs. They must involve parents, academic and CTE teachers, administrators, faculty, career guidance and academic counselors, local business and industry representatives in an annual evaluation of CTE programs. Texas school districts have local advisory committees for CTE that are involved in decisions related to the implementation, improvement, and evaluation of CTE programs (Texas Education Agency, 2007, pp. 21-22).

According to Phipps, Osborne, Dyer, and Ball (2008) advisory committees should have a direct impact on program planning and design. The committee should support the agricultural science teacher and provide advice on programming. Advisory committees provide a link between the community and the agricultural program, thus allowing the community to have an influence on students' learning.

Many barriers may exist in the development and implementation of advisory committees at the secondary level. Advisory committees rely heavily on the support of the community in which the school is located. Talbert, Vaughn, Croom and Lee (2007) report that at certain times, there may be a lack of community involvement associated with agricultural science programs as well as lack of support for the program from the administration at the school. As federal and state accountability increases in public education, agricultural science teachers find themselves teaching state mandated 
curriculum. Some agricultural teachers may not see the need for advisory committees once curriculum decisions have been made by the state (Talbert et al., 2007).

Teacher preparation from colleges and universities could also affect the use of advisory committees. In a study used to determine challenges for induction teachers, Burris and Keller (2008) found that new teachers had a limited preparation on how to organize and maintain an advisory committee, making it one of the lowest perceived challenges to new teachers entering the profession of agricultural education.

\section{Purpose}

Secondary agricultural science falls directly under the Agriculture, Food and Natural Resources umbrella of the Texas Education Agency that develops the Texas State Plan for Career and Technical Education, requiring agricultural science programs in Texas to have an advisory committee. However, in Texas, little about advisory committees is known or to what extent programs are currently utilizing advisory committees. The purpose of this study is to explore and describe the characteristics of advisory committees in agricultural science programs in Texas as well as examine the current influence and perceived functions of advisory committees on program change and development.

\section{Objectives of the Study}

1. Describe the characteristics of secondary agricultural science programs which were used in this study (size of school, program, and level of competition above the local level in agricultural science or FFA activities).

2. Describe the perceived functions of advisory committee recommendations on agricultural science program change and development. 
3. Describe characteristics of advisory committees used by agricultural science programs in Texas.

4. Describe the influence that advisory committees have had on program change and development.

5. Compare the perceived functions of advisory committees between programs with advisory committees and programs without advisory committees.

6. Describe the relationship between perceptions of advisory committees and a program characteristic.

\section{Definition of Terms}

Advisory Committee- Also referred to as "advisory council" is defined in this research as a group of individuals responsible for assisting agricultural science programs in program evaluation and/or development.

Agricultural Education- The study of agriculture in secondary, public schools. Agricultural Science Program- A program of instruction that incorporates FFA, SAE and classroom instruction into a learning environment for secondary students.

Agricultural Science Teacher- A person who has been certified by the Texas State Board of Educators Certification as highly qualified to provide instruction in agricultural science at the middle school and / or secondary level.

Career Clusters- Group of career and technical education course offerings grouped on commonality.

CTE- Career and Technical Education, for this purpose of this research CTE is referred to a sequence of courses offered at the secondary public school level to 
prepare students for future career choices. CTE also referred to as "CATE" (career and technical education) or Vocational Education. For the purpose of this study CTE will be used.

CTE Director-Position responsible for the administration of career and technical education programs at the local school level.

FFA- The youth organization also known as the National FFA Organization whose mission statement is to make a positive difference in the lives of students by developing their potential for premier leadership, personal growth and career success through agricultural education (National FFA Organization, 2010). Perceived Function- Functions of an advisory committee were cited from referenced agricultural education text. Agricultural science teachers used a Likert-type scale to report their opinions of what an advisory committee should do.

Influence- Suggested areas of influence of an advisory committee were cited from referenced agricultural education text. Agricultural science teachers used a Likert-type scale to determine the amount of influence that their current advisory committee on decisions regarding programming.

\section{Basic Assumptions}

Several assumptions of the researcher were made pertaining to agricultural science programs in Texas as well as teachers who represent those programs.

1. Participants in this study will have general knowledge of advisory committees and will answer questions pertaining to the study to the best of their ability.

2. Participants in this study will answer questions honestly. 
3. Participants in this study will be practicing agricultural teachers in the State of Texas.

4. Participants in this study will be able to answer the questions via electronic communication based on an online survey system.

5. The random sample will be representative of the population.

\section{Limitations}

1. First year agricultural science instructors may have limited knowledge of agricultural advisory committees. This may affect their ability to have opinions on the current influence of advisory committees and perceived functions of what an advisory committee should do.

2. Non-response of this study could be partly attributed to the electronic questionnaire used for this study being distributed through electronic mail, which may have been blocked by some school censoring programs unknown to the researcher.

\section{Significance of the Study}

In the months and years to come, Texas Agricultural Education will be changing. According to the Gerald Young of Vocational Agriculture Teachers Association of Texas (VATAT) as of fall 2010, agricultural science teachers in Texas will have the opportunity to teach Professional Communications for Speech Credit, Floral Design for Fine Arts credit, Advanced Animal Science and Soil Science for the forth science of Texas graduation requirements. Also, Mathematical Applications in Agriculture, Food and Natural Resources will serve as a fourth math credit for graduation requirements (2010). Recently, Texas has also adopted a new set of Texas Essential Knowledge and Skills or 
TEKS. TEKS are competencies of each class offered that students must be able to recognize and perform upon completion of the course. Agricultural Science TEKS are state mandated and fall under the Career and Technical Education umbrella of the Texas Education Agency (Texas Education Agency, 2010). Texas has now expanded agricultural science to include agriculture, food, and natural resources.

With these and other changes taking place, many teachers across Texas are left with decisions on what classes to teach and how those classes will be taught in order to fit the needs of the students in the community. Also, as new teachers enter the profession of agricultural education, many teachers may not possess the skills or education to establish and maintain an advisory committee. This research study will offer insight on how Texas agricultural education instructors are using advisory committees to help guide the direction of their programs to as well as determine the current influence of advisory committees in local communities. This is a timely study which will use current data to support changes for the future. The study will be used to educate both current and future agricultural education teachers. These teachers will have a better understanding of what an advisory committee consists of as well as discover program planning decisions that can be made with the use of an advisory committee to best fit the needs of the community and its students. 


\section{Chapter II}

\section{Review of Literature}

\section{Purpose and Objectives}

The purpose of this study was to explore and describe the characteristics of advisory committees in agricultural science programs in Texas as well as examine the current influence and perceived functions of advisory committees on program change and development. In order to guide this study the following research objectives were developed:

1. Describe the characteristics secondary agricultural science programs which were used in this study (size of school, program, and level of competition above the local level in agricultural science or FFA activities).

2. Describe the perceived functions of advisory committee recommendations on agricultural science program change and development.

3. Describe characteristics of advisory committees used by agricultural science programs in Texas.

4. Describe the influence that advisory committees have had on program change and development.

5. Compare the perceived functions of advisory committees between programs with advisory committees and programs without advisory committees.

6. Describe the relationship between perceptions of advisory committees and a program characteristic. 


\section{Introduction}

Agricultural advisory committees have influence in a school and community and should be used to improve and support the agricultural program (Waley \& Sutphin, 1987). Advisory committees among other adult organizations are considered by many to be integral parts of agricultural science programs (Dormody, Seevers, \& Clason, 1996). The advisory committee's purpose, according to public law 94-482 (1976) is to provide the school district or agency with current job needs and to provide information regarding relevancy of courses that are currently being offered.

\section{Program Planning}

Program planning is directed toward a change in behavior of the learner groups or learner systems. There are two assumptions to consider in program planning. First, programming consists of universal components existing at different levels or over time spans. Secondly, program planning exists in two dimensions, the planned program and plans of action to achieve that program (Boone, Safrit, \& Jones, 2002). The program that is planned relies directly on the plan of action to achieve the program. Many organizations rely or depend on the participation of group members in some aspects of planning new or changed programs (Pawlak \& Vinter, 2004). Group members play active roles in the determination of programming, planning and goals. The level of participation by these members in the planning process commonly affects the end result of the program. 


\section{Theoretical Framework}

\section{Overview}

Program development is the art of implementing and designing actions taken to achieve effective educational programs (Boyle, 1981). Many issues must be considered when developing programs. Along with these issues, the educator must play a role in the planning process and assist in determining a course of action for the program. The achievement of this goal is based on the effort of the educator to allow for the utilization of concepts in order to utilize a program development framework.

The ultimate goal of an education program is to help people accomplish something that will benefit them (Boyle, 1981). Through this definition, Boyle identified a rational model for program planning that works in reality when dealing with people. Program development will begin with a situation, and often times, a problem or need will not be identified until the program planning process has begun. The educator must be open to use the most appropriate effort to program plan.

Boyle (1981) proposed a model for educational program planning. This model illustrates the relationship between concepts and procedures used to accomplish program planning goals. The model consists of six concepts: programmer, involvement, advisory groups, survey, informal measures, and need identification and analysis. These concepts are illustrated as separate but equal procedures used for needs of program development. A modified version of this model has been used in order to represent the needs of secondary agricultural education programs (Figure 2.1). This study will focus on the advisory group function of Boyle's model. 


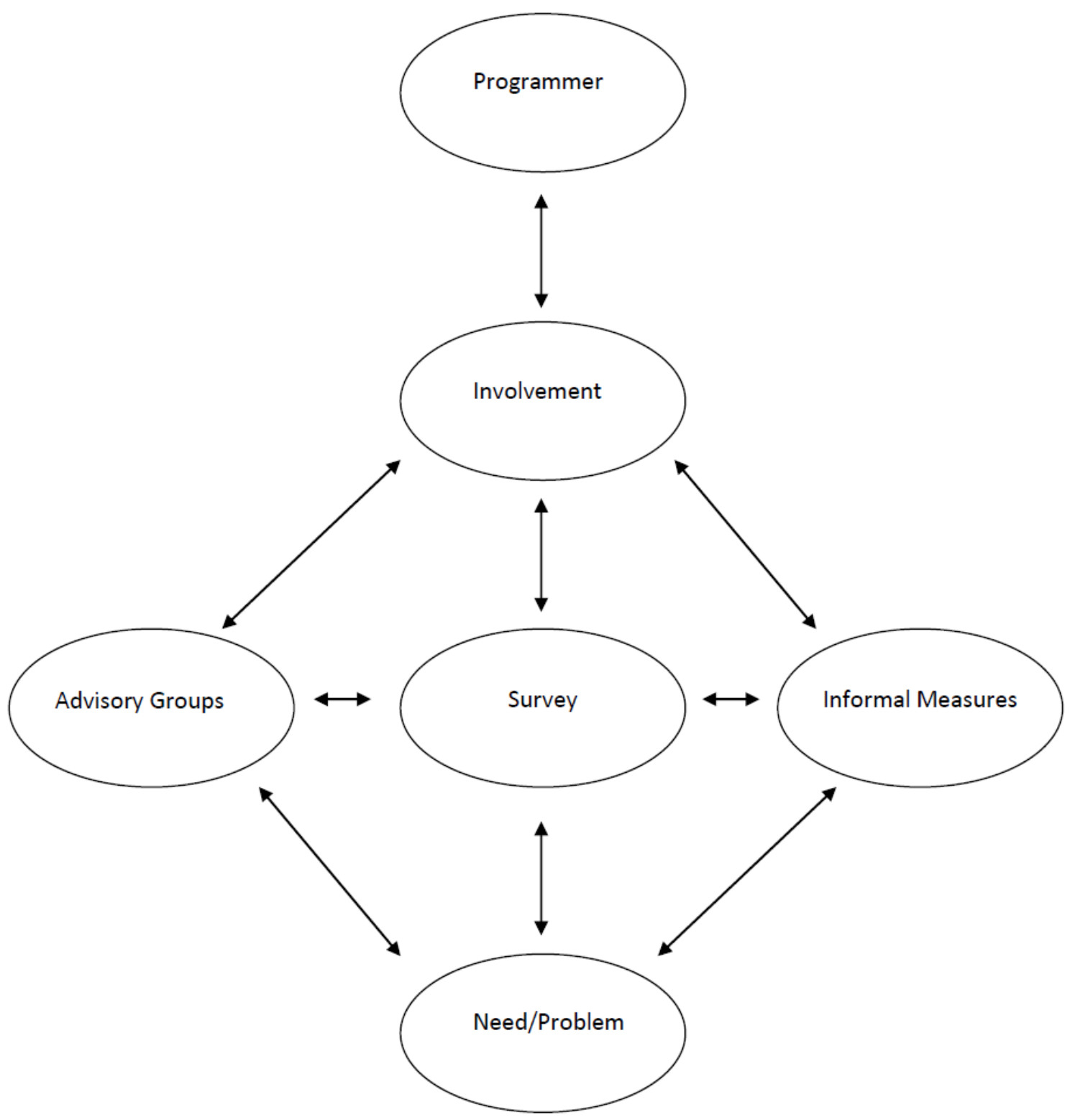

Figure 2.1. Relationships between Concepts and Procedures of Program Planning 


\section{Programmer}

Change commonly affects people, and those who are responsible for change in behavior are commonly known as target agents or change agents. The amount of change that is brought to a targeted system and the level of change involved depend on the programmer's position in social society (Boyle, 1981). The community in which the educator works will depend on the workload of the educator. Larger communities require more time spent planning. The size of the community can affect the decisions of the programmer on the scope and direction of the program. Analysis of the program, goal setting, implementation, and evaluation can all become roles of the programmer throughout the planning and implementation process. The community can affect the role of the programmer. Government structure, size, demographics, population, and racial mix can all affect the role of the programmer in the community. The programmer can personally attribute feelings toward emphasis in certain areas. If the programmer feels that followers are capable of taking situations into their own hands, a more encouraging role may be taken by the programmer, rather than an authoritarian approach.

The role of the programmer may involve four roles: analyst, stimulator, facilitator, and encourager. The analyst role is essential for defining problems and identifying needs of the program. The stimulator role of the programmer is to link the needs of the students to the best resources available. The encourager role utilizes the programmer's ability to motivate students to reach their maximum personal abilities as well as benefit the group. For the purpose of this study, the agricultural science teacher will represent the programmer. 


\section{Involvement}

Involvement uses citizens in the program development process, connects citizens to the process and creates a situation to occupy the participation of the citizens. Participation involves utilizing citizens to actively make decisions toward certain plans (Boyle, 1981). It is the responsibility of the programmer to know the purpose of involving citizens and select a method for utilizing them. Programmers can involve citizens in a variety of different methods. A programmer can visit, discuss, debate, and consult with citizens on a regular basis in order to involve them in program decision making opportunities.

\section{Advisory Groups}

The operation of organizations and programs throughout the country is being increasingly influenced by the involvement of people through advisory committees (Boyle, 1981). The purpose of an advisory committee must be identified by the programmer by first considering the objectives of the program. Members of advisory committees are asked to perform duties based on the function of the program.

Boyle (1981) describes several tasks that advisory committees are likely to perform at the program development level: collect and analyze data for problem identification, identify problems, identify needs and resources, make decisions on priority problems, identify alternative problems or needs, and create awareness of the program and needs to other people in the community. The programmer can make decisions on which citizens to involve in program planning based on who can make a significant contribution to program development. This study will determine the role of the advisory committee in program planning and development at the local level. 


\section{Surveys}

Boyle (1981) identified that a survey is a popular method for involving large numbers of people in order to gain information or data needed. When data is collected, this data can be tabulated or discussed in further detail. Surveys may be carried out by the programmer through the use of mail, personal interview, or telephone interview. Boyle (1981) suggests that some advantages to using surveys is the ability to gain information from a large variety of people.

\section{Informal Measures}

Boyle (1981) suggests that informal measures refer to personal meetings with clients. Informal measures include knowledge and experience that is gained by the programmer relating to and interacting with clientele in the community. Informal measures are knowledge gained in another form other than methods such as a task force, ombudsman, advocacy planning or a formal hearing.

\section{Identification of Problems and Needs}

Educators face the dilemma of too many problems to solve or too much curriculum to teach. Priorities must be established in order to identify the most important problems or needs (Boyle, 1981). Boyle introduced six categories that have been established to provide a basis for the decision making process in the identification of problems: community, clientele, politics, organization, resources and personnel.

Social community provides groups, trends, goals, and values to the programming issue. Clientele provide specific needs of the program. Politics of the community should be considered when making programming decisions. Communities recognize multiple levels of government and expect program priorities to fall within those 
guidelines. A programmer must consider the community when establishing programming needs as decisions are made toward what programming efforts to be offered.

Certain communities may expect different levels of participation from the organization on education. A programmer must consider resources that are available to the program and utilize those resources to meet the needs of the community. Personnel must also be considered in the identification of problems and needs.

For the purpose of this study, teaching partners in agricultural science programs will be considered. A step in problem priority setting is establishing how decisions will be made. The programmer will have the ultimate decision on what programming to offer, but it is up to the programmer to use citizens of the community to guide this discussion.

\section{Legislation}

In 1963, in order to expand influence over state programs, the Vocational Education Act of 1963 was passed (Hayward \& Benson, 1993). It was at this point where the term, "advisory committee" was first introduced in legislation in order to periodically review vocational education programs and laws at the state level. Section 12 of the Vocational Education Act of 1963 states that the committee shall have 12 members and shall, to the extent possible, include persons familiar with the vocational education needs of management and labor, persons familiar with the administration of state and local vocational education programs, other persons with special knowledge, experience, or qualifications with respect to vocational education, and persons representative of the general public (Vocational Education Act, 1963). 
The Education Amendments of 1977 is the first mention of advisory committees for vocational education at the secondary level. For the first time, advisory committees were required by federal law for school districts receiving federal funding. The advisory committee's purpose, as stated in legislation, was to provide the school district or agency with current job needs and provide information regarding relevancy of courses that were currently being offered (Public Law 94-482, 1976).

In 1984, the Carl D. Perkins Vocational Education Act, revised in 1998 and 2006 reemphasized the need for advisory committees by promoting states to take action in their plans to require local vocational education to evaluate their programs using some form of advisory committee. The amendment of the Carl D. Perkins act states in Section 134, of Public Law 105-220:

describe how parents, students, academic and career and technical education teachers, faculty, administrators, career guidance and academic counselors, representatives of tech prep consortia, representatives of business and industry, labor organizations, representatives of special populations, and other interested individuals are involved in the development, implementation and evaluation of career and technical education programs assisted under this title and how such individuals and entities are effectively informed about, and assisted in understanding, the requirements of this title, including career and technical programs of study (Carl D. Perkins Amendment, 2006).

The 2007 Texas State Plan for Career and Technical Education for 2008-2013 responded to the demands of the Carl D. Perkins act by stating in number 6 that: 
Texas requires that eligible recipients annually evaluate their Career and Technical Education (CTE) programs. They must involve parents, academic and CTE teachers, administrators, faculty, career guidance and academic counselors, local business and industry representatives in an annual evaluation of CTE programs. Texas school districts have local advisory committees for CTE that are involved in decisions related to the implementation, improvement, and evaluation of CTE programs (Texas Education Agency, 2007, p. 21).

\section{Previous Studies}

\section{Beginning Agricultural Science Teachers}

The establishment of advisory committees in towns and communities for agricultural science programs is a concern to beginning agriculture science teachers. Burris and Keller (2008) identified six common competencies as high needs for beginning teachers. Advisory committees were identified as one of the high needs. Teachers were asked to rank their perceived competency on a list of items closely related to the field. Among the lowest ranking items surveyed was a beginning teacher's perceived competency to organize and maintain an advisory committee. Burris and Keller reported a possible explanation for low perceived advisory committee competencies; teachers might be simply unaware of the importance of a committee during the early stages of their careers.

While researching the perceived competencies of agricultural educators, Layfield and Dobbins (2002) found that one of the top five competencies that differed between experienced agricultural science teachers and beginning agricultural science teachers is their utilization of advisory committees. Layfield and Dobbins (2002) compared the 
results of their study to Missouri beginning agricultural science teachers perceived needs, the researchers found the needs of beginning teachers could represent a national trend. The researchers recommended that beginning teacher's needs should be prioritized when planning professional development conferences.

While researching problems that face beginning agricultural teachers, Myers, Dyer, and Washburn (2005) reported that organizing an effective advisory committee was a major problem. Beginning teachers may also believe that the establishment of an advisory committee may be important, but may believe that they do not possess the skills to establish an advisory committee. Myers et al. recommended that agricultural education training programs continue to emphasize the importance of using an advisory committee and expand curriculum on how to manage adult organizations.

\section{Secondary Agricultural Science}

The status and influence of agricultural science advisory committees was investigated in California (Whaley \& Sutphin, 1987). The study was conducted in two stages. First, agricultural science programs with active advisory committees were identified and characteristics and influences of their advisory committees were measured. Next, of those who identified utilizing an advisory committee, $50 \%$ were randomly selected and their school principal as well as advisory committee chairperson was mailed a researcher developed questionnaire. With a $78 \%$ response rate, 314 questionnaires were returned. Out of the 314 returned, 210 participants reported utilizing and advisory committee, while 71 reported not utilizing an advisory committee.

Participants in this study were asked to describe the most important recommendations made by their agricultural advisory committee. These 
recommendations fit into five categories. These five categories included revise curriculum, develop a school farm, support California agricultural education programs, recommend science credit for agricultural courses, and recommend equipment needs for the program.

According to Whaley and Sutphin (1987) the majority of advisory committees had five to 10 members. Agricultural advisory committees provided a worthwhile function and were used by a majority of agricultural programs in California. Programs that do not use advisory committees were not in compliance with the California state standards and not taking advantage of an important resource. Advisory committees in California focused most of their attention toward curriculum and development, management of facilities, equipment selection and use, and program evaluation. Advisory committees in California were commonly viewed similarly by school principals, and advisory committee chairmen.

Whaley and Sutphin (1987) recommended in their study that agricultural advisory committees should be established for all agricultural programs. Operational procedures conclude that all members should be provided in writing, a list of the committee functions and goals. Advisory committee members should include school principals, and use local school board members to make recommendations for new advisory committee members. Agricultural science teachers, advisory committee members, and school administrators should work together to establish and improve communications and working relationships between each other. Advisory committees should identify and focus on large problems and should not waste time with small, insignificant issues where their influence is limited. Whaley and Sutphin recommended that future studies should 
investigate why perceptions of advisory committees differ from school administrators, agriculture teachers and advisory committee members and determine the organizational and operational variables that are associated with a successful agricultural advisory committee.

Advisory committees are considered to be integral parts of secondary agricultural education programs. Dormody, Seevers, and Classan (1996) reported that $90 \%$ of agricultural programs nationwide utilized an advisory committee. Advisory committees were surveyed and results found that nearly $90 \%$ of the time, agricultural science advisory committees were advising teachers on course content, assessing equipment, and evaluating the agricultural science program. Dormody et al. recommended that advisory committees adopt goals of assisting with public relations between the community and the program and assist in identifying community resources for the agricultural science programs.

Studies relating to FFA membership above the chapter level should be identified in order to examine characteristics of programs. FFA leadership activities and leadership development events have been reported to effect FFA member participation (Dormody \& Seevers, 1994). Of 25 levels of participation in FFA events in Oklahoma, more than half of FFA members surveyed only participated in eight of the events. Events were classified in this study to include leadership development events, career development events, public speaking, SAE activities, chapter meetings and holding office (Dormody \& Seevers, 1994)

Lawver and Lee (1990) examined a comparison between members and nonmembers of vocational agricultural teachers associations. Lawver and Lee reported that 
agricultural teachers who were members of professional organizations could be distinguished from non members by a set of variables describing their degree of professionalism, importance of the organizational role and benefits and teacher characteristics. Teachers who were members of a professional organization had a higher number of students who were also members of a professional organization.

\section{Advisory Committees in Extension Education}

Research on advisory committees in secondary agricultural education is somewhat limited. However, extensive research has been conducted in the characteristics, influence, and uses of advisory committees in extension education. Advisory committees serve a similar purpose to that of the secondary agricultural science advisory committee. Well organized and managed advisory committees are a key to quality extension programming (Barnett, Johnson \& Verma, 1999).

\section{Use of Advisory Committees in Extension Education}

Ebling (1985) found that extension advisory committees should aid in educational program planning but should also add to budget development, presentations, consult on public relations and inform those who want to know more about extension programming. Advisory committees are not directly involved in programming presentation but because of the diverse background of the committee, the opinions and input of the members should allow extension agents to step back and see a different perspective or point of view. Wegenhoft and Holt (1988) suggested that the advisory committee should aid in the implementation and evaluation of program goals. 


\section{Views of Advisory Committees in Extension Education}

The utilization of an advisory committee can add to the overall quality of educational programming in extension education. The committee should reflect the needs of the community. However, advisory committee member views toward advisory committees can vary depending on the situation. Black, Howe, Howell, and Bedker (1992) reported that advisory committees in extension programming are mostly represented by members involved in farming, 4- $\mathrm{H}$, home economics, and forest management. This representation signifies that advisory committees have not kept up with the changing clientele and changing program emphasis of extension education. Barnett et al. (1999) reported that many members of advisory committees did not have a clear understanding of their role on the committee. Most committee members felt that the purpose of the committee was to identify problems and give direction to the county extension agent. Advisory committees are involved in giving advice to county agents as well as making decisions and implementing programs.

Barnett et al. (1999) examined the overall effectiveness of cotton advisory committees as perceived by extension agents and other advisory committee members. The study concluded that 19 of 22 parishes in Louisiana had functioning advisory committees. Most committee members felt that the purpose of the committee was to identify problems and give direction to the county extension agent. Agents, on the other hand, did not view the recommendations of advisory committees as pertinent during the final decision making process, but did recognize the advisory committees role in acceptance in the community. When expressing views toward committee functions, agents reported that advisory committees are very important for advisement. Most agents 
reported that the most important function of an advisory committee was to provide advice to county agents regarding programming. Committee members also saw advisement as the main function of the committee overall and viewed advisory committees as a source of support for county extension agents. In regard to the function of an advisory committee, members reported they had a strong involvement in advisement of agents, but a weak involvement in communication and no involvement in implementation. Both agents and advisory committee members indicated that committee members had a strong involvement in decision making but a weak involvement in program acceptance. In regard to educational programming, Barnett et al. reported that county agents should be left to program educational activities, while committee members felt that they should be involved in the programming process through the function of evaluation. Black et al. (1992) reported that advisory committee members often held extension educators in high regard and felt as if they were providing input that was useful and needed.

\section{Development of an Extension Advisory Committee}

The development of an extension advisory committee is an important aspect of program planning in extension education. The process of development is challenging to new extension agents and viewpoints on the development of a committee vary from researcher to researcher. The development of an advisory committee is among one of the greatest challenges a new extension agent may face (Place, 2007).

When developing new advisory committees, Wegenhoft and Holt (1988) suggested several strategies for implementation. An extension agent must develop a working relationship with committee members and potential committee members in the community. An agent must gain an idea about how committee members will respond to 
certain situations. It is the role of the extension agent to select a chairperson to lead the committee and aid in the selection process of a leadership team or set of officers. Once officers are selected, members and those who are in a leadership role, must receive proper training from extension personnel. Workshops should be held to develop the leadership skills of the committee members and literature should be provided on meeting management and working with other members. Wegenhoft and Holt (1988) suggested that the agent develop a working relationship with the committee chairperson so that he or she is familiar enough with the committee to take on tasks appropriately. The extension agent should come to advisory committees prepared with an agenda that was developed with the assistance of the chairman. Following the meeting, a copy of the minutes should be sent to all committee members with a note of appreciation for their service.

In order to gain information about the development of advisory committees, Black et al. (1992) researched the selection of advisory committee members in New Hampshire. A researcher developed questionnaire was developed and sent to 126 members of New Hampshire advisory committees. The purpose of the study was to gain insight about the orientation and selection of new advisory committee members. Black, et al. reported that of those who responded to the questionnaire, almost half of the members were appointed or brought to the group by an extension agent. Other members joined an advisory committee with a balloting process. The study reported that the most common tasks that involved the approval or disapproval of advisory committees included development and implementation of extension programming, expenditure of county funds, hiring and firing of extension educators, and salary changes of county extension educators. 
Ebling (1985) in a study involving the use of an advisory committee recommends that extension staff work with committee chairman to identify committee members or leaders by those who seem to be interested in extension's mission. At an initial meeting, a subcommittee can prepare the operating guidelines of the committee. A committee member may agree to a three year term of service, but a one year break is required before a member can serve another consecutive three year term. In this study, a member had not served more than five years. Ebling reported there were several advantages to using an identification approach to committee member selection. Advantages include new members who can bring fresh ideas that often work well in extension programming.

Barnett et al. (1999) recommend that to improve agent management of an advisory committee, an agenda should be prepared prior to committee meetings. Advisory committee members should be recognized publically for their support of extension programs, and minutes of advisory committee proceedings should be mailed to producers involved with educational programming.

\section{Reference Materials Related to Agricultural Science Advisory Committees}

Several agencies, organizations, and agriculture teacher education institutions have published reference materials related to successful planning, organization, and implementation of advisory committees in secondary agricultural programs. These

publications are considered to be referred practical application guides toward a successful advisory committee implementation. Practical application guides have consistent themes but vary according to state statutes and the situation of the local agricultural program. There were five themes derived from practical application guides: establishing need for 
advisory committees, organization of advisory committees, management of advisory committees, agriculture program evaluation, and promotion of the agricultural program.

\section{Need for Advisory Committees}

An advisory committee is a group of individuals who provide advice for educational programs (Talbert, Vaughn, Croom, \& Lee, 2007). The advisory committee is a useful tool used by many agriculture education teachers and can assist schools and teachers as they continue to improve the quality of instruction in their local agriculture programs.

An advisory committee that is a vital, valued part of the agricultural program that provides many benefits to the school, program, teachers, and students. The local agricultural science teacher with the assistance of a local advisory committee will develop a program which reflects the local vision of the community (University of Georgia, N.D.). The National FFA Organization (1998) suggests that advisory committee members play an important role in the development of a successful agricultural science program. Committee members are considered to be experts in their perspective fields. Advice of the advisory committee should be taken seriously by the institution or program

officials. A partnership with local business and industry leaders can change the culture of the community so that businesses and schools can provide opportunities for students. The main goal of advisory committees is program development and improvement. Many employers are prepared to make a substantial contribution to education but they want to play a significant role and be equal partners in the process (University of MissouriInstructional Materials Laboratory [IML], 1997). 


\section{Organization}

An agricultural science teacher must be convinced of the need for an advisory committee. The teacher should study functions and advantages of an advisory committee, as well as visit advisory committees currently in operation (National FFA Organization, 1998). It is necessary to meet with school administration and inform them of the purpose of an advisory committee. School administrators can provide support in the development of an advisory committee as well as provide assistance in identifying members (Talbert et al., 2007). According to The University of Missouri's Instructional Materials Laboratory (1997) the key to beginning an advisory committee depends on the operational guidelines of the committee. Guidelines consist of goals, objectives, rules and procedures of the advisory committee. During the first organized meeting of the advisory committee, guidelines should be adopted and changes should be amended. It is important for the agricultural science teacher to identify any barriers that may block the program and the committee from implementing plans (National FFA Organization, 1998).

When selecting members for advisory committees, one of the first mistakes that can be made includes appointing favorite parents involved in the program. Selection of favorite parents almost always ensures that difficult issues will not be discussed in fear of offending the agricultural science teacher or school administration (Talbert et al., 2007). It is necessary to prepare a list of people from which committee members will be selected. Use the school administration and school board to make a final selection of committee members. An agricultural science teacher should include local business, industry, and school related people on the committee. People who do not have close ties 
to the program should also be selected (National FFA Organization, 1998). An agricultural science advisory committee consists of local volunteers who are usually appointed by the local education agency or governing board (University of MissouriIML, 1997). An official letter of invitation should be sent to prospective committee members. The agricultural science teacher should determine if prospective members are interested in serving on the committee. The advisory committee should be representative of agriculture in the community (University of Georgia, N.D.). The ideal size of an advisory committee depends on the size of the community. The size of the committee should be large enough to represent the needs of the community but small enough to be managed effectively (University of Missouri-IML, 1997). The University of Georgia recommended that advisory committees range from seven to 11 members with the idea size being nine members. Members should be appointed for three year terms. Talbert et al. (2007) also recommend that advisory committee members be elected with three year terms in order to maintain instructional memory on the committee and prevent burnout of committee members. The University of Georgia suggests members of advisory committees should meet the following qualifications: interested in education and youth, interested in agricultural education program, time available to serve, wiliness to serve, reputation for honesty, someone who is forthright with their views but for the improvement of the group, and respected by peers in the community.

\section{Management}

The initial meeting of the agricultural advisory committee will set the tone and pace of the committee's work in the agricultural science program (Talbert et al., 2007). The first meeting will give members an idea of what to expect from the advisory 
committee (University of Georgia, N.D.). The University of Missouri-IML (1997) recommended that the agricultural education teacher establish and publicize a time, date, and location for each meeting, and notify members in advance. It might be necessary to call members and remind them of the meeting as well as send a reminder postcard prior to the meeting.

In a large capacity, the success of the committee depends on the management team. Management teams may consist of a chairperson, vice-chairperson, recorder or secretary, and a facilitator (University of Missouri-IML, 1997). It is the agricultural science teacher's responsibility to become a non-voting facilitator of the advisory committee (University of Georgia, N.D.). The chairperson plays an important role in the development of a committee and serves as a liaison between the advisory committee and the agricultural science teacher and the school administration (Talbert et al., 2007). The advisory committee chairman and the agricultural science teacher should prepare an agenda prior to the meeting date (University of Georgia). Agendas should be sent to members prior to the meeting to allow for members to think about upcoming discussions and bring materials that could be useful to the purposes of the meeting (University of Missouri-IML).

\section{Program Evaluation}

A well-functioning advisory committee will evaluate the current agricultural program to determine if it is providing students with realistic career training and preparation (National FFA Organization, 1998). It is essential that the program advisory committee begin working with an in-depth evaluation of the agricultural science program. The advisory committee needs good data about the program before it can begin to make 
decisions regarding the program. Negative results can occur when an agricultural science teacher meets with an advisory committee and recommendations regarding curriculum, planning and goals are made without an evaluation of the program. Sometimes recommendations cannot be carried out because they are inconsistent with the data of the program or the community. In some cases, evaluation of the program may have already been conducted through a state or local accreditation program. Many schools are regularly audited by an accreditation agency for quality assurance purposes (Talbert et al., 2007). The University of Missouri- IML (1997) suggested that programs should be evaluated after some recommendations have been made so that the committee can determine the extent to which the group is reaching its goals, extent to which the recommendations and actions of the committee have strengthened the agricultural program, and to determine future direction for the program.

\section{Promotion}

To share the work of a program partnership in the community and maintain enthusiasm for the partnership, an educator should consider ways to promote activities and their benefits. Recognizing committee members is one of the best ways to promote the program in the community and create goodwill among the members. Members of advisory committees are not paid for their services. Recognition of members becomes crucial to increase productivity, improve the group's interaction, and increase member satisfaction. Most members of committees are willing to attend meetings regularly and work hard if their suggestions are taken seriously, and they are given feedback regarding their recommendations and efforts (University of Missouri- IML, 1997). Talbert et al. (2007) suggested that when advisory committee members end their terms of service, 
reward them accordingly. The University of Missouri- IML (1997) recommended several ways to reward members and promote program progress throughout the community: issue press releases and photographs announcing appointment of a committee member, report to alumni groups and other meetings how the committee has been of service, invite committee members to important events and functions, place members names on display board or plaque at school, hold a reception or thank you dinner each year at the school, include members in announcements or reports made by the school district administration.

Creating public awareness of the advisory committee can increase public knowledge of the program and recognize the group's contributions to the program. There are several ways to create public awareness of the program and the advisory committee. Several of these ways include: open houses and tours of the program facilities, newsletters which include a schedule of events, newspaper publicity which includes FFA contest results, and radio or television announcements including agriculture program activities that were beneficial to students (University of Missouri- IML, 1997).

\section{Summary}

The information presented in this chapter demonstrates and supports the need for effective advisory committees in secondary agricultural science programs. Program planning in agricultural science utilize an advisory committee with Boyle's (1981) model for relationships between concepts and procedures of program planning. Program planning utilizing advisory committees can increase program awareness in the community and tailor the program reflect to the needs, wants and desires of the community. Advisory committees are common practice in extension education. The advisory committees are used to reflect the educational programming needs of the 
community. The utilization and organization of advisory committees is a need of beginning teachers in agricultural education. There are many approaches to developing an advisory committee in a local community. Common themes of advisory committee development include establishing a need for an advisory committee, organizing an advisory committee, managing an established advisory committee, utilizing an advisory committee for program evaluation, and promoting a program through an advisory committee. 


\section{Chapter III}

\section{Methodology}

\section{Purpose and Objectives}

The purpose of this study was to explore and describe the characteristics of advisory committees in agricultural science programs in Texas as well as examine the current influence and perceived functions of advisory committees on program change and development. In order to guide this study the following research objectives were developed:

1. Describe the characteristics secondary agricultural science programs which were used in this study (size of school, program, and level of competition above the local level in agricultural science or FFA activities).

2. Describe the perceived functions of advisory committee recommendations on agricultural science program change and development.

3. Describe characteristics of advisory committees used by agricultural science programs in Texas.

4. Describe the influence that advisory committees have had on program change and development.

5. Compare the perceived functions of advisory committees between programs with advisory committees and programs without advisory committees.

6. Describe the relationship between perceptions of advisory committees and a program characteristic. 


\section{Research Design}

This quantitative study was non-experimental and utilized a descriptivecorrelational research design. According to Gall, Gall and Borg (2007), correlational research is defined as "A type of investigation that seeks to discover the direction and magnitude of the relationship among variables through the use of correlational statistics" (p. 636). Gall, Gall, and Borg also define descriptive research as, "A type of investigation that measures the characteristics of a sample or population on pre-specified variables" ( $p$. 638). The study is descriptive as in that it allowed secondary agricultural science instructors to describe their agricultural science program characteristics and the characteristics of advisory committees. The variables explored included program characteristics and perceptions of advisory committees based on the views of the secondary agricultural science teacher.

\section{Population and Sample}

The population of this study is current agricultural science instructors in Texas who represent the programs in which they are employed. A frame was obtained from the state association of agricultural science teachers (VATAT) listing agricultural science

programs in Texas. After the frame was deemed accurate by checking for duplications or omissions it was determined that there were currently 1037 agricultural science programs in Texas. Based upon Krejcie and Morgan's (1970) table for determining sample size from a given population, 278 programs represent the appropriate sample size in order to generalize the results of this study to all agricultural science programs in Texas. Programs were randomly selected using a random design feature of Microsoft Excel 
2007. An agricultural science teacher at each selected program was identified to participate in the study.

\section{Instrumentation}

Using Zoomerang, an instrument was developed to obtain data related to six predetermined objectives from survey participants. The instrument was divided into four sections. The four sections were:

1. Characteristics of programs participating in the study.

2. Agriculture Science Teacher's perceptions of advisory committee functions.

3. Influence of current advisory committees.

4. Open-ended response section. If you do not have an advisory committee, please tell us why.

The scales of measurement for this instrument range from nominal scales of measurement to open-ended questions to asking the participant to indicate a level of agreement containing questions based on a Likert-type scale. The instrument was developed specifically for this research

\section{Question Content}

The first question asked the participants if they utilize an advisory committee. If the participant responded "no", the participant was not able to answer questions regarding their current advisory committee influence or current advisory committee characteristics.

Section one of the questionnaire sought to describe characteristics of programs. Three questions were asked regarding the status of teachers at each of the surveyed programs. Questions varied from the total number of agricultural science teachers at each 
program, as well as if how many teachers are members of the VATAT. The status of the FFA program in place was determined by asking FFA membership and level of participation above the local level. Participants were also asked if their school district currently employs a CTE or Vocational Director.

The second section of the instrument measured the perceived functions of what an advisory committee should do based on opinions of the agricultural science teacher. A Likert-type scale was used to determine perceived functions on 11 programming areas based off referenced text regarding the implementation of advisory committees (Talbert, Vaughn, \& Croom, 2005); and (Phipps, Osborne, Dyer, \& Ball, 2008). Programs who participated used a level of influence scale to determine their views of the importance in an advisory committee on program planning and development. This study used the same levels of influence that Whaley and Sutphin (1987) used in their study of advisory committees in California. Perceived functions ranged on a Likert-type scale of one to five where $1=$ no influence, $2=$ limited influence, $3=$ some influence, $4=$ moderate influence, and $5=$ extreme influence. This question was designed to be answered by both programs that currently are using advisory committees and those that are not.

Section three sought to describe the influence of current agricultural program advisory committees as well as determine the characteristics of current advisory committees in Texas. Using Likert-type items, teachers were asked to rate their level of influence with statements regarding their current advisory committee. This Likert-type scale indicated levels of influence. The scale ranged from 1-5 where $1=$ no influence, $2=$ limited influence, $3=$ some influence, $4=$ moderate influence, and $5=$ extreme influence. There were 11 items of concentration developed using referred text regarding the 
implementation of advisory committees (Talbert, Vaughn, \& Croom, 2005); and (Phipps, Osborne, Dyer, \& Ball, 2008). It is important to note that the same referenced text items were used for both the perceived functions and current influence Likert-type scales.

The remainder of the section sought to describe current advisory committees in Texas. In addition to the Likert- type scale, several additional questions were asked regarding size of committee, characteristics of employment background of committee members, meeting agendas, and appointment or election of new members. This section also determined whether the program's advisory committee also served as a livestock booster club or parental support group.

Section four was an open-ended question for participants to leave responses regarding their use of advisory committees. The question was only completed by those not formally using advisory committees in order to explain their reasoning for not having a committee in place. Not all participants chose to complete this section of the questionnaire.

\section{Validity}

Gall, Gall, and Borg (2007) define validity as "the appropriateness, meaningfulness, and usefulness of specific inferences made from test scores" (p. 657). Validity of this instrument was tested using a panel of experts with experience in the field of agricultural education from Texas Tech University. The experts used in this research examined the instrument for face validity prior to data collection. Avy, Jacobs and Razavieh (2002) stated, "A survey should have face validity; it should appear valid for its intended purpose" (p. 409). 
The content for this instrument was developed using referenced materials from previous studies and accepted publications used for agricultural education. Whaley and Sutphin (1987) conducted a similar study in California. This study was used as a guide in developing questions to fit the objectives of the study. A panel of experts in Agricultural Education at Texas Tech University was used to determine if the instrument was valid, therefore measuring what it is intended to measure.

\section{Reliability}

The instrument was pilot tested in order to determine reliability. The researcher chose 22 programs that were not chosen to participate in the actual study to pilot test the instrument. The pilot test was conducted between January 11, 2010, and January 15, 2009. The pilot test returned $100 \%$ participation. After the conclusion of the pilot test, the researcher analyzed data utilizing Statistical Package for Social Sciences (SPSS) for Windows Version 17.0. Cronbach's alpha coefficients were used to measure internal consistency in order to establish reliability. According to Gall, Gall and Borg (2007) Cronbach's alpha coefficients are defined as "a measure of the internal consistency of a test containing items that are not scored dichotomously, based on the extent to which testtakers who answer a given test item one way respond to other items in a similar way" (p. 637). Cronbach's alpha revealed a reliability Cronbach's alpha coefficient of .95 for characteristics and influence, and .94 perceived functions. Nunnally (1967) suggested that Cronbach's alpha coefficients of .5-.6 are acceptable in the early stages of research. The Cronbach's alpha coefficients in this research exceed acceptable levels. Slight changes were made to questions based upon recommendations of pilot test participants. 


\section{Data Collection Procedures}

Data collection for this study occurred during the months of January and February 2010. This study was conducted over the course of five weeks. For the purpose of this study, a modified version of Dillman's Mail and Internet Surveys (2007) was used as a guideline for data collection and correspondence with sample participants. The first initial contact made with subjects $(n=287)$ contained information regarding the purpose and call for participation in the study. Following the introductory email, five additional contacts were made. Participants were contacted via email for all correspondence during the course of this study. The participants were first contacted with an email explaining the nature of the study, purpose and objectives. The participants were then told that in seven days, further information would follow regarding the study and a website link to participate. The following week, a second email was sent to the sample asking for participation. A link to the online survey host, Zoomerang was included in the email. In the following weeks, three reminder notices were sent in seven day intervals, asking for participation in the study. On February 24, 2010, a final notice was sent the all remaining sample members who had not yet participated. The questionnaire was closed 24 hours following the final notice for participation. Table 3.1 shows this process, along with the number of responses obtained with each stimulus. Each week, before a reminder was sent, information regarding participation was gathered, and a letter of appreciation was sent to each of those who participated. 
Table 3.1.

Participant Contact $(N=6)$

\begin{tabular}{lcccc}
\hline Contact & Content & Beginning Date & End Date & Responses \\
\hline 1 & Introduction & $1 / 20 / 2010$ & $1 / 27 / 2010$ & 0 \\
2 & Invitation & $1 / 27 / 2010$ & $2 / 3 / 2010$ & 65 \\
3 & Reminder & $2 / 3 / 2010$ & $2 / 10 / 2010$ & 39 \\
4 & Reminder & $2 / 10 / 2010$ & $2 / 17 / 2010$ & 25 \\
5 & Reminder & $2 / 17 / 2010$ & $2 / 24 / 2010$ & 15 \\
6 & Final Notice & $2 / 24 / 2010$ & $2 / 25 / 2010$ & 18 \\
& & & 162 \\
\hline
\end{tabular}

The instrument used in this study was delivered to sample participants using an online host called Zoomerang. Participants in this study chose to participate by clicking on an online link that directed the participants to the questionnaire. A welcome screen greeted the participants and again told the participants that their participation in the study was optional and that their responses would be kept confidential. Also, participants were given contact information if they had any questions regarding the nature of the study. Participants were reminded that they should allow approximately 15 minutes to complete the questionnaire.

Participants were first asked if their program currently utilized an advisory committee. If participants responded that their program did not have an advisory committee, they were not responsible for answering questions regarding the influence or characteristics of their current committee. All participants responded to questions 
regarding characteristics of their program and what they believed an advisory committee's functions should be.

In order to generalize the findings of this study to all agricultural science programs in Texas, it was necessary to account for the non-respondents of this study. Linder, Murphy, and Briers (2001) suggested that one method used to account for nonresponse includes comparing early and late respondents. Late respondents are most likely classified as those who participated in the survey during the final "wave" during the last stimuli sent. Linder, Murphy, and Briers recommend that the minimum number of late respondents equal 30. In this research, the final stimuli resulted in 20 participants, therefore, non response was considered to be the last two stimuli of the study $(n=35)$. Early respondents were categorized as the first three stimuli, and the number of participants which resulted from each "wave". Likert-type scale questions were compared using independent T-test. When these variables for early and late respondents were compared, independent T-test revealed no significant difference between early and late respondents. Therefore this study can be generalized to Texas agricultural science programs.

\section{Data Analysis}

The objectives of this study were used as a guide to determine the data analysis procedures used in this research. Data was analyzed using Statistical Package for Social Sciences (SPSS) Version 17.0. Data was imported into Microsoft Excel 2007 from Zoomerang to be coded. Data were then imported into SPSS from Microsoft Excel 2007. Objectives in this study used frequencies, percentages, means, and standard deviations to describe and examine comparisons of the characteristics and influence of advisory 
committees in secondary Texas agriculture science programs. Pearson product moment correlations and point-biserial coefficient correlations were used to determine relationships that existed between agricultural advisory committees and a program characteristic such as size of agricultural program and total FFA member enrollment. Davis Conventions (1971) were used to describe the strength of the relationship between characteristics. Scores from the 11 Likert-type items were averaged and summated for each individual participant. An average perception score was then analyzed using an independent t-test. Differences in means of perception were then analyzed between programs who utilize an advisory committee and those who do not utilize an advisory committee. 


\section{Chapter IV}

\section{Findings}

\section{Purpose and Objectives}

The purpose of this study was to explore and describe the characteristics of advisory committees in agricultural science programs in Texas as well as examine the current influence and perceived function of advisory committees on program change and development. In order to guide this study the following research objectives were developed:

1. Describe the characteristics secondary agricultural science programs which were used in this study (size of school, program, and level of competition above the local level in agricultural science or FFA activities).

2. Describe the perceived functions of advisory committee recommendations on agricultural science program change and development.

3. Describe characteristics of advisory committees used by agricultural science programs in Texas.

4. Describe the influence that advisory committees have had on program change and development.

5. Compare the perceived functions of advisory committees between programs with advisory committees and programs without advisory committees.

6. Describe the relationship between perceptions of advisory committees and a program characteristic. 


\section{Population and Sample}

The population of this study was current agricultural science instructors in Texas who represent the programs in which they are employed. A document was obtained from VATAT listing agricultural science programs in Texas. After the frame was deemed reliable by checking for duplications or omissions it was determined that there are currently 1037 agricultural science programs in Texas. Based upon Krejcie and Morgan's (1970) equation for determining sample size from a given population, 278 programs were required to generalize the results of this study to all agricultural science programs in Texas. Programs were randomly selected using a random design feature of Microsoft Excel 2007. An agricultural science teacher at each program chosen was randomly selected to participate in the study. Using random programs from a frame ensured that the programs selected remained unbiased and impartial. A total of 162 programs participated in this study with a response rate of 58.3\%.

\section{Objective One}

Objective one sought to describe characteristics of programs which were used in this study. Characteristics were assessed for both students who are currently enrolled in agricultural science classes and those who are currently FFA members. Table 4.1 describes the number of students at each high school which participated in the study. It is important to note that all participants did not respond to every question of the instrument but, those who did not respond to all questions were included and offer insight in this study. The number of secondary students (grades 9-12) ranged from 25-3500 with a mean of 927.55 and a standard deviation of 985.19 . There were 160 participants who reported the number of students enrolled in agricultural science classes $(n=160)$. 
Students enrolled in agricultural science classes ranged for 20-600 with a mean of 134.96 $(S D=134.96)$. Table 4.1 also illustrates FFA enrollment for participants in this study. The range of FFA members in programs ranged from 5-551 and had a mean of 81.04 (SD $=73.85)$ members per program.

Table 4.1

Students Representing Agricultural Science Programs in Texas

\begin{tabular}{lccc}
\hline Student & $M$ & $S D$ & Range \\
\hline High School Enrollment & 927.55 & 985.19 & $25-3500$ \\
Program Enrollment & 134.96 & 101.67 & $20-600$ \\
FFA Membership & 81.04 & 73.85 & $5-551$ \\
\hline
\end{tabular}

Programs were asked to indicate which activities above the chapter level that their FFA chapter typically participated. These findings are reported in Table 4.2. It is important to note that participants could indicate several or all events above the chapter level. The most common participation was reported in Leadership Development Events $(n=153,94.4 \%)$ and Career Development Events, $(n=149,92 \%)$ of participants. Attendance at conventions was the third most common activity with $90.7 \%$ participating ( $n=144$ ). In addition to other events, $88.9 \%$ of respondents reported that their programs participate in Supervised Agricultural Experience Programs, $81.5 \%(n=132)$ reported leadership camps, and 63.6\% $(n=103)$ advanced degrees. The lowest participation was reported in the areas of proficiency awards $40.1 \%(n=65)$ and agriscience fair $16 \%(n=$ 26). 
Table 4.2

Participation in Activities above the Chapter Level $(N=162)$

Activity

1. Leadership Development Events

2. Career Development Events

3. Supervised Agricultural Experience

4. Conventions

5. Leadership Camps

6. Advanced Degrees

7. Proficiency Award Programs

\section{$f$}

153

149

144

147

132

103

65

26
$\%$

94.4

92.0

88.9

90.7

81.5

63.6

40.1

8. AgriScience Fair

Note. Programs could select multiple activities. The mean participation was 2.86 events with a standard deviation of .77 .

Table 4.3 describes cumulative chapter activities. The majority of programs, $27 \%,(n=$ 44) participated in seven events above the chapter level, followed by $25.9 \%(n=42)$ who reported participating in six events. There were only a few programs that reported participating in less than four events above the chapter level. 
Table 4.3

Cumulative Participation above the Chapter Level $(N=162)$

\begin{tabular}{lcc} 
Cumulative Participation & $f$ & $\%$ \\
\hline 0 & 1 & 0.6 \\
1 & 3 & 1.9 \\
2 & 3 & 1.9 \\
3 & 5 & 3.1 \\
4 & 17 & 10.5 \\
5 & 31 & 19.1 \\
6 & 42 & 25.9 \\
7 & 44 & 27.2 \\
8 & 14 & 8.6 \\
\hline
\end{tabular}

To get a better understanding of programs that participated in this study, agricultural teachers who represented programs were also examined. Years of teaching agricultural science is reported in Table 4.4. The mean teaching experience was reported as 12.59 years and standard deviation of years teaching experience is reported as 10.44 . It is important to point out that frequency counts show that the highest frequencies occurs in the lower number of teaching experience, one year $(n=12)$, two years experience $(n=9)$, three years experience $(n=14)$, four years experience $(n=12)$, and five years experience $(n=11)$. 
Participants indicated the number of instructors who were currently teaching agricultural science at their program. On average there are 1.65 teachers per program with a standard deviation of .78 . Table 4.4 reports the frequency and percentage for teachers employed at each program. Participants report that $51.8 \%(n=83)$ of programs have one teacher, 34\% ( $n=55)$ of programs have two teachers, $11.7 \%(n=19)$ report three teachers, and $2.5 \%(n=4)$ report four teachers. Participants also indicated the number of members at each program who were members of the Vocational Agriculture Teachers Association of Texas. Less than 5\% of programs responded that no teachers were members of VATAT, while $48.1 \%(n=78)$ reported one member, $32.7 \%(n=53)$ reported two members, $10.5 \%(n=17)$ reported three members, $1.9 \%(n=3)$ reported 4 members, and $.6 \%(n=1)$ reported having nine members. Table 4.4 also describes the frequency counts and percentages for programs that have teachers who are members of the Vocational Agriculture Teachers Association of Texas. Programs also reported whether or whether not a CTE Director is used in their program. Participants $(n=162)$ reported that 53.4\% $(n=88)$ do not have a CTE Director while $45.7 \%(n=74)$ reported that their program currently employs a CTE director. 
Table 4.4

Program Agricultural Science Teachers $(n=161)$

\begin{tabular}{|c|c|c|c|c|}
\hline Program Characteristic & $f$ & $\%$ & $M$ & $S D$ \\
\hline Teaching Experience ${ }^{a}$ & & & 12.59 & 10.49 \\
\hline Number of Teachers & & & 1.65 & .78 \\
\hline 1 & 83 & 51.2 & & \\
\hline 2 & 55 & 34.0 & & \\
\hline 3 & 19 & 11.7 & & \\
\hline 4 & 4 & 2.5 & & \\
\hline VATAT Members & & & 1.60 & 1.01 \\
\hline 0 & 8 & 4.9 & & \\
\hline 1 & 78 & 48.1 & & \\
\hline 2 & 53 & 32.7 & & \\
\hline 3 & 17 & 10.5 & & \\
\hline 4 & 3 & 1.9 & & \\
\hline 9 & 1 & .6 & & \\
\hline \multicolumn{5}{|l|}{ CTE Director } \\
\hline Used & 74 & 45.7 & & \\
\hline Not Used & 88 & 53.4 & & \\
\hline
\end{tabular}

Note. ${ }^{\mathrm{a}} n=162$ 


\section{Objective Two}

Objective two sought to describe the perceived functions of advisory committees in secondary agricultural science programs. Agricultural programs were asked to complete a section regarding their perceived opinion of what an advisory committee should do regarding program change, planning, and development. The section included used 11 competencies of advisory committees and measured the perceived functions of advisory committees on program planning with a Likert-type scale ranging from one to five where 1 = no influence, 2 = limited influence, 3 = some influence, $4=$ moderate influence, and $5=$ extreme influence. Programs who participated in this study indicated that advisory committees should play a role in facilitating a public communication link between the public and the program $(M=3.70, S D=1.16)$, evaluating the agricultural program $(M=3.26, S D=1.04)$, and identifying facility modifications $(M=3.21, S D=$ 1.05). Identifying equipment needs $(M=3.16, S D=1.08)$ was also indicated as having "some influence" on agricultural program planning. The three lowest areas of perceived functions were hiring new instructors $(M=2.55, S D=1.14)$, reviewing instructional materials $(M=2.50, S D=0.94)$, and approving budgets $(M=2.44, S D=1.13)$. Other items included determining objectives of the program $(M=2.92, S D=0.94)$, determining courses to be offered $(M=2.75, S D=0.85)$, and approving courses to be taught to students $(M=2.61, S D=0.97)$. The average perception score for the Likert-type items was $2.86(S D=0.78)$. The results of this objective are reported in table 4.5. 
Table 4.5

Perceived Functions of Advisory Committees $(n=159)$

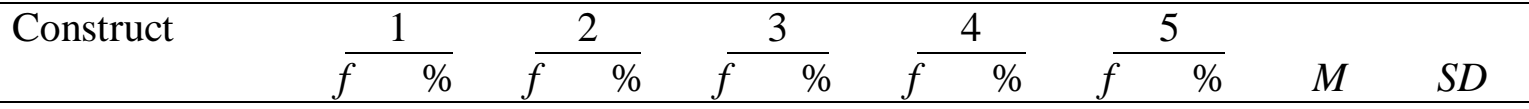

Communication

Link $^{\mathrm{a}}$

$$
\begin{array}{llllllllllll}
9 & 5.6 & 14 & 8.6 & 41 & 25.3 & 46 & 28.4 & 48 & 29.6 & 3.70 & 1.16
\end{array}
$$

Evaluating the

$\begin{array}{lllllllllllll}\text { Ag Program }^{\mathrm{a}} & 9 & 5.6 & 26 & 16.0 & 54 & 33.3 & 53 & 32.7 & 16 & 9.9 & 3.26 & 1.04\end{array}$

Identifying

Facility

$\begin{array}{lllllllllllll}\text { Modifications } & 9 & 5.6 & 30 & 18.4 & 54 & 33.3 & 50 & 30.9 & 16 & 9.9 & 3.21 & 1.05\end{array}$

Identifying

Equipment

Needs

$\begin{array}{llllllllllll}12 & 7.4 & 29 & 17.9 & 57 & 35.2 & 44 & 27.2 & 17 & 10.5 & 3.16 & 1.08\end{array}$

Determining

Objectives

$\begin{array}{llllllllllll}11 & 6.8 & 38 & 23.5 & 69 & 42.6 & 35 & 21.6 & 6 & 3.7 & 2.92 & 0.94\end{array}$

Determining

Courses $^{\mathrm{a}}$

$\begin{array}{llllllllllll}11 & 6.8 & 46 & 28.4 & 76 & 46.9 & 22 & 13.6 & 3 & 1.9 & 2.75 & 0.85\end{array}$

Approving

Courses

$\begin{array}{llllllllllll}25 & 15.4 & 53 & 32.7 & 59 & 36.4 & 18 & 11.1 & 4 & 2.5 & 2.61 & 0.97\end{array}$

Reviewing

Courses for

Relevance $^{\mathrm{a}}$

$\begin{array}{llllllllllll}22 & 13.6 & 49 & 30.2 & 62 & 38.3 & 18 & 11.1 & 7 & 4.3 & 2.61 & 1.01\end{array}$

Hiring New

Instructors

$\begin{array}{llllllllllll}35 & 21.6 & 42 & 25.9 & 50 & 30.9 & 24 & 14.8 & 8 & 4.9 & 2.55 & 1.14\end{array}$

Reviewing

Instructional

Materials $^{\mathrm{a}}$

$\begin{array}{llllllllllll}24 & 14.8 & 52 & 32.1 & 65 & 40.1 & 13 & 8.0 & 4 & 2.5 & 2.50 & 0.94\end{array}$

Approving

$\begin{array}{lllllllllllll}\text { Budgets }^{\mathrm{a}} & 38 & 23.5 & 47 & 29.0 & 45 & 27.8 & 21 & 13.0 & 7 & 4.3 & 2.44 & 1.13\end{array}$

Note. ${ }^{\mathrm{a}}(n=158), 1=$ no influence, $2=$ limited influence, $3=$ some influence, $4=$ moderate influence, $5=$ extreme influence, overall mean $=2.86(S D=0.78)$. 


\section{Objective Three}

Of those who participated in the study, $43 \%(n=70)$ reported that they utilize an advisory committee while $57 \%(n=92)$ responded that they currently do not utilize an advisory committee. Table 4.6 reports the use of advisory committees by FFA area in Texas. Texas FFA Area 3 had the highest participation in the study $(n=24)$, followed by Area $10(n=20)$, and Area $9(n=18)$.

Table 4.6

Use of Advisory Committees in Texas Reported by Area $(n=162)$

\begin{tabular}{lcc} 
Use of Advisory Committee & Yes & No \\
FFA Area One & 6 & 7 \\
FFA Area Two & 4 & 12 \\
FFA Area Three & 10 & 10 \\
FFA Area Four & 7 & 9 \\
FFA Area Five & 6 & 4 \\
FFA Area Six & 8 & 9 \\
FFA Area Seven & 6 & 6 \\
FFA Area Eight & 6 & 13 \\
FFA Area Nine & 5 & 8 \\
FFA Area Ten & 12 & \\
\hline
\end{tabular}


Over half of the participants in this study indicated they did not currently utilize an advisory committee. Participants who reported that their program is currently using an advisory committee, $40 \%(n=28)$ responded that their advisory committee is also considered a livestock booster club, parent support group, livestock show board or fundraising group. Programs who reported having an advisory committee $65.7 \%(n=46)$ reported that their advisory committees does not represent any other CTE programs other than agricultural sciences. Table 4.7 describes current use of advisory committees in Texas.

Table 4.7

Use of Advisory Committees in Texas $(n=70)$

\begin{tabular}{lcc}
\hline Type of Committee & $f$ & $\%$ \\
\hline Utilize Agriculture Advisory Committee & 70 & 43.2 \\
Advisory Committee also Booster Club & 28 & 40.0 \\
Agriculture Exclusive Committee & 46 & 65.7 \\
\hline
\end{tabular}

Table 4.8 displays the number of members who serve on advisory committees. Participants $(n=70)$ indicated that an average of $6.56(S D=3.96)$ members serve on advisory committees. Frequency counts and percentages were used to reflect results. Eighteen programs identified five members on their committee, followed by three members and six members both having eight respondents. 
Table 4.8

Number of Advisory Committee Members $(n=70)$

\begin{tabular}{lll}
\hline Member & $f$ & $\%$ \\
\hline 1 & 1 & 1.4 \\
2 & 3 & 4.3 \\
3 & 8 & 11.4 \\
4 & 6 & 8.6 \\
5 & 18 & 25.7 \\
6 & 8 & 11.4 \\
7 & 9 & 12.9 \\
8 & 4 & 5.7 \\
9 & 3 & 4.3 \\
10 & 2 & 2.9 \\
11 & 1 & 1.4 \\
12 & 1 & 2.9 \\
13 & 3 & 1.4 \\
16 & 2 & 4.3 \\
\hline 20 & & 1.4 \\
\hline
\end{tabular}


Table 4.9 indicates advisory committee meeting attendance. Participants recorded that agricultural science teachers attend advisory committee meetings in $88.6 \%(n=62)$ of the programs. This was followed by parents or guardians $81.4 \%(n=57)$, local business or industry representatives $77.1 \%(n=54)$, school principal $44.3 \%(n=31)$, career and technology directors $32.9 \%(n=23)$, school board members $21.4 \%(n=15)$, school superintendent 20\% ( $n=14)$, student representatives $20 \%(n=14)$ assistant school principal $15.7(n=11)$, local elected officials $8.6 \%(n=6)$ and university professors $7.1 \%(n=5)$. 
Table 4.9

Attendance of Advisory Committee Meetings $(n=70)$

\begin{tabular}{lcc} 
Attendees & $f$ & $\%$ \\
\hline $\begin{array}{l}\text { Agricultural Science } \\
\text { Teacher }\end{array}$ & 62 & 88.6 \\
Parents or Guardians & 57 & 81.4 \\
Local Business Officials & 54 & 77.1 \\
School Principal & 31 & 44.3 \\
Career and Technology & 23 & 32.9 \\
Director & 15 & 21.4 \\
School Board Members & 14 & 20.0 \\
School Superintendent & 14 & 20.0 \\
Student Representatives & 11 & 17.7 \\
Assistant Principal & 6 & 8.6 \\
Local Officials & 5 & 7.1 \\
University Professors & &
\end{tabular}

Note. Participants had an option of selecting multiple attendees of advisory committee meetings.

The characteristics of an advisory committee meeting are reported in Table 4.10. When preparing an agenda for an advisory committee meeting, participants identified the agricultural science teacher $(n=31,44.3 \%)$ as the most common source for creating an agenda. Agricultural Science Teacher was followed by Career and Technology Director $(n=15,21.4 \%)$, advisory committee president $(n=12,17.1 \%)$, School Administration Member $(n=8,11.4 \%)$, and other $(n=4,5.7 \%)$. Other members were identified by 
participants as counselor and federal program directors. Two participants did not indicate a written response to "other". Table 4.10 also reports who from the advisory committee has the responsibility of keeping records or official minutes. Of the 70 participants who responded utilizing an advisory committee, $35.7 \%(n=25)$ of programs have a secretary on the committee keep official minutes or records of the meeting. Followed by agricultural science teachers $31.4 \%(n=22)$, school administrators $17.1 \%(n=12)$ and $8.6 \%(n=6)$ of programs surveyed indicated another member on their program committee. Approximately six percent $(n=4)$ of programs reported that they do not keep minutes or records of their meetings, while $1.4 \%(n=1)$ indicated another choice by marking "other". There are several programs who currently receive funds for conducting the activities of business of the program advisory committee. Table 4.8 displays the various methods that funding is provided to advisory committees. The majority of programs reported receiving no funding for their advisory committees $(68.6 \%, n=48)$. Some programs reported receiving funds only through fundraising efforts $(10.0 \%, n=7)$. Programs also reported receiving funds through the school district's general budget $(8.6 \%, n=6)$, the chapter or program budget $(2.9 \%, n=2)$, and $2.9 \%(n=2)$ marked "other". Responses of "other" were unspecified by the participants. 
Table 4.10

Characteristics of Advisory Committees $(n=70)$

\begin{tabular}{|c|c|c|}
\hline & $f$ & $\%$ \\
\hline \multicolumn{3}{|l|}{ Preparer } \\
\hline Agricultural Science Teacher & 31 & 44.3 \\
\hline Career and Technology Director & 15 & 21.4 \\
\hline Advisory Committee President & 12 & 17.1 \\
\hline School Administration Member & 8 & 11.4 \\
\hline Other & 4 & 5.7 \\
\hline \multicolumn{3}{|l|}{ Recorder } \\
\hline Secretary & 25 & 35.7 \\
\hline Agricultural Science Teacher & 22 & 31.4 \\
\hline School Administration Member & 12 & 17.1 \\
\hline Member on Committee & 6 & 8.6 \\
\hline No Records or Minutes Kept & 4 & 5.7 \\
\hline Other & 1 & 1.4 \\
\hline \multicolumn{3}{|l|}{ Funding Source } \\
\hline No Funding & 48 & 68.6 \\
\hline Fundraising Efforts & 7 & 10.0 \\
\hline District General Budget & 6 & 8.6 \\
\hline Program FFA / Chapter Budget & 2 & 2.9 \\
\hline Other & 2 & 2.9 \\
\hline
\end{tabular}


Table 4.11 reports who identifies new program advisory committee members for service. The majority of programs $70.0 \%(n=49)$ reported that their advisory committee used an agricultural science teacher to identify new members for service. Existing members of the advisory committee are also used in $28.6 \%(n=20)$ of the programs to identify new members. Participants also identified career and technology directors $(n=$ $13,18.6 \%)$ school principals $(n=7,10 \%)$, school district superintendent $(n=4,5.7 \%)$, and "other" $(n=4,5.7 \%)$. Participants identified "other" in all four cases as being a career and technical education teacher other than the agricultural science teacher. School board members were identified the least among those who identify advisory committee members $(n=1,1.4 \%)$. Program advisory committee selection was assessed in this study. The majority of participants $(n=49,70.0 \%)$ reported that appointment was the most common method of selection for advisory committees. The second most common response was for advisory committee members to be elected for service $(n=8,11.4 \%)$. Programs also reported that advisory committee members are asked $(n=7,10.0 \%)$. Programs identified "other" as members whom asked to serve on the advisory committee $(n=3,4.3 \%)$. Volunteer to be a member on the committee was reported as the least common response from programs $\quad(n=2,2.9 \%)$. 
Table 4.11

Identification of New Advisory Committee Members $(n=70)$

\begin{tabular}{|c|c|c|}
\hline Method & $f$ & $\%$ \\
\hline \multicolumn{3}{|l|}{ Identification Method } \\
\hline Agricultural Science Teacher & 49 & 70.0 \\
\hline Existing Committee Member & 20 & 28.6 \\
\hline CTE Director & 13 & 18.6 \\
\hline Principal & 7 & 10.0 \\
\hline Superintendent & 4 & 5.7 \\
\hline Other & 4 & 5.7 \\
\hline School Board Members & 1 & 1.4 \\
\hline \multicolumn{3}{|l|}{ Selection Method } \\
\hline Appointed & 49 & 70.0 \\
\hline Elected & 8 & 11.4 \\
\hline Asked & 7 & 10.0 \\
\hline Other & 3 & 4.3 \\
\hline Volunteer & 2 & 2.9 \\
\hline
\end{tabular}

Note. Participants had an option to select multiple methods for the identification of potential advisory committee members. 
Table 4.12 displays frequencies for which programs identified members of their advisory committee who have careers related to agriculture. The majority of programs reported that less than half of their members have careers related to agriculture (32.9\%, 23). The least common response was having no members of the committee who have careers related to agriculture $(n=4,5.7 \%)$.

Table 4.12

Members Who Have Careers Related to Agriculture $(n=70)$

\begin{tabular}{lcc} 
Committee Members & $f$ & $\%$ \\
\hline Less than Half & 23 & 32.9 \\
Majority & 21 & 30.0 \\
Half of Members & 12 & 17.1 \\
All Members & 9 & 12.9 \\
None of Members & 4 & 5.7 \\
\hline
\end{tabular}

Advisory committee meeting frequency was reported by programs in Table 4.13. Most commonly, programs reported only conducting advisory committee meetings once per academic semester $(n=33,47.1 \%)$. This response was followed by; once per academic year $(n=14,20.0 \%)$, monthly $(n=11,15.7 \%)$ quarterly $(n=11,15.7 \%)$ and semi-monthly $(n=1,1.4 \%)$. None of the programs indicated that their advisory committee meetings were conducted weekly. 
Table 4.13

Frequency of Advisory Committee Meetings $(n=70)$

\begin{tabular}{lcc} 
Occurrence & $f$ & $\%$ \\
\hline Once per Academic Semester & 33 & 47.1 \\
Once per Academic Year & 14 & 20.0 \\
Quarterly & 11 & 15.7 \\
Monthly & 11 & 15.7 \\
Semi-Monthly & 1 & 1.4 \\
Weekly & 0 & 0.0 \\
\hline
\end{tabular}

\section{Objective Four}

Objective four sought to describe advisory committee influence on program planning by programs that currently use advisory committees. Influence was measured using 11 objectives of advisory committees and measured on a Likert-type scale, where 1 $=$ no influence, $2=$ limited influence, $3=$ some influence, $4=$ moderate influence, and 5 $=$ extreme influence. Levels of influence of current advisory committees are reported in Table 4.14. Programs who currently use advisory committees believed that their advisory committee had the most influence in three areas, creating a public communication link between advisory committees and programs $(M=3.46, S D=1.21)$, evaluating the agricultural program $(M=3.19, S D=1.15)$, and identifying the equipment needs of the agricultural program $(M=2.91, S D=1.09)$. Programs who had advisory committees believed that approving budgets $(M=2.00, S D=1.13)$, hiring new teachers $(M=1.90$, $S D=1.22)$, reviewing instructional materials $(M=1.87, S D=0.96)$. Programs who had 
advisory committees also reported levels of influence for five additional constructs, determining objectives of the program $(M=2.87, S D=1.08)$, identifying facility modifications $(M=2.83, S D=1.14)$, reviewing courses for accuracy and relevance $(M=$ 2.21, $S D=1.09)$, determining courses to be offered $(M=2.40, S D=0.97)$ as well as approving student courses of study $(M=2.07, S D=1.09)$. Mean influence score for the Likert-type items was $2.52(S D=1.21)$. 
Table 4.14

Influence of Advisory Committees ( $n=70$ )

\begin{tabular}{llllllllllllll}
\hline Construct & $f$ & $\%$ & $\frac{2}{f}$ & $\%$ & $f$ & $\%$ & $\frac{4}{f}$ & $\%$ & $\frac{5}{f}$ & $\%$ & $M$ & $S D$ \\
\hline
\end{tabular}

Communication

Link

$\begin{array}{llllllllllll}8 & 4.9 & 4 & 2.5 & 20 & 12.3 & 24 & 14.8 & 14 & 8.6 & 3.46 & 1.21\end{array}$

Evaluating the

Agriculture

Program

$\begin{array}{llllllllllll}8 & 4.9 & 8 & 4.9 & 25 & 15.4 & 21 & 13.0 & 8 & 4.9 & 3.19 & 1.15\end{array}$

Identifying

Equipment

$\begin{array}{llll}10 & 6.2 & 11 & 6.8\end{array}$

$6.8 \quad 27$

$16.7 \quad 19$

$\begin{array}{llll}11.7 & 3 & 1.9 & 2.91\end{array}$

1.09

Determining

Objectives $^{\mathrm{a}}$

$\begin{array}{llllllllllll}8 & 4.9 & 17 & 10.5 & 21 & 14.8 & 16 & 9.9 & 4 & 2.5 & 2.87 & 1.08\end{array}$

Identifying

Facility

Modifications

$\begin{array}{llllllllllll}11 & 6.8 & 14 & 8.6 & 24 & 14.8 & 16 & 9.9 & 4 & 2.5 & 2.83 & 1.14\end{array}$

Reviewing

Courses for

Relevance

$\begin{array}{llllllllllll}25 & 15.4 & 14 & 8.6 & 23 & 14.2 & 7 & 4.3 & 1 & 0.6 & 2.21 & 1.09\end{array}$

Determining

Courses to be

Offered

$\begin{array}{llllllllllll}15 & 9.3 & 21 & 13.0 & 25 & 15.4 & 9 & 5.6 & 0 & 0.0 & 2.40 & 0.97\end{array}$

Approving

Courses $^{\mathrm{a}}$

$\begin{array}{llllllllllll}27 & 16.7 & 19 & 11.7 & 16 & 9.9 & 5 & 3.1 & 2 & 1.2 & 2.07 & 1.09\end{array}$

Approving

Budgets

$\begin{array}{llllllllllll}33 & 20.4 & 14 & 8.6 & 14 & 8.6 & 8 & 4.9 & 1 & 0.6 & 2.00 & 1.13\end{array}$

Hiring New

Instructors

$\begin{array}{llllllllllll}38 & 23.5 & 14 & 8.6 & 9 & 5.6 & 5 & 3.1 & 4 & 2.5 & 1.90 & 1.22\end{array}$

Reviewing

Instructional

\begin{tabular}{lrrrrrrrrrrrr} 
Materials & 33 & 20.4 & 17 & 10.5 & 16 & 9.9 & 4 & 2.5 & 0 & 0.0 & 1.87 & 0.96 \\
\hline Note: ${ }^{\mathrm{a}} n=69.1=$ no influence, $2=$ limited influence, $3=$ & some influence, & $4=$ moderate
\end{tabular} influence, $5=$ extreme influence, overall mean $=2.52(S D=1.21)$ 


\section{Objective Five}

Objective five sought to examine the comparison between agricultural science teacher's opinions toward the functions of advisory committees between programs who utilize an advisory committee and those that do not utilize an advisory committee. An independent t-test was used for analysis. Programs who reported utilizing advisory committees $(n=70)$ reported a mean perception score of $32.30(S D=7.81)$. Programs who do not utilize an advisory committee $(n=90)$ had a mean perception of $30.89(S D=$ 9.02).

A hypothesis was made. In the population of agricultural programs there is a significant difference between perceptions of functions between programs who utilize an advisory committee and programs who do not utilize an advisory committee. The null hypothesis states that in the population of agricultural programs there is not a significant difference between perceptions of functions between programs who utilize an advisory committee and programs who do not utilize an advisory committee. The alpha level for this research was set at .05 a priori. A t-test indicated there is no statistical significant difference with a test value of $1.04(p=.30)$. Therefore, the null hypothesis was not rejected and it is assumed that there is no statistical difference between perceived functions of programs who utilize advisory committees and programs who do not utilize advisory committees. The results of the t-test are reported in Table 4.15. 
Table 4.15

T-test of Utilization of Advisory Committees Compared to Non-utilization

\begin{tabular}{lccccc} 
Advisory Committee & $n$ & $M$ & $S D$ & $t$ & $p$ \\
\hline Yes & 70 & 32.30 & 7.81 & 1.04 & .30 \\
No & 92 & 30.89 & 9.02 & & \\
\hline
\end{tabular}

\section{Objective Six}

The relationship between the participant's perception of advisory committees and a dependant variable was reported in Table 4.16. Participants reported a negative low ( $r$ $=-.14$ ) relationship between years teaching experience and perceptions of advisory committees. The number of teachers at each program reported similar findings. Programs reported a negative negligible $(r=-.11)$ relationship between the number of agricultural science students at each program and the participant's perception of advisory committees. A negligible relationship $(r=.02)$ was reported between the number of current FFA members at each program and the participant's perception of advisory committees. Table 4.16 also displays the relationship between a program characteristic and use of an advisory committee. Participants reported a moderate relationship $\left(r_{p b}=.44\right)$ between years of teaching experience of an agricultural science teacher and the use of an advisory committee. Those who participated in the study also reported a low $\left(r_{p b}=.23\right)$ relationship between the number of teachers at each program and the current use of an advisory committee. Programs reported a low $\left(r_{p b}=.18\right)$ relationship between the number of students enrolled in the program the presence of an advisory committee. Current FFA membership and the current use of an advisory committee also reported a 
low $\left(r_{\mathrm{pb}}=.22\right)$ relationship. When the perception of advisory committees was compared to the current use of advisory committees, a negligible $\left(r_{p b}=.08\right)$ relationship was found. Program chapter activity above the local level was compared to current use of advisory committees. A low relationship $\left(r_{p b}=.20\right)$ was found between chapter activity participation and the current use of advisory committees.

Table 4.16

Relationship between Perceived Functions and Use of Advisory Committees

\begin{tabular}{lccc}
\hline Characteristic & $n$ & $\begin{array}{c}\text { Perception } \\
(r)\end{array}$ & $\begin{array}{c}\text { Presence of } \\
\text { Advisory Committee } \\
\left(r_{p b}\right)\end{array}$ \\
\hline Teaching Experience & 161 & -.14 & .44 \\
Number of Teachers & 161 & -.11 & .23 \\
Agricultural Science Students & 159 & -.03 & .18 \\
Current FFA Members & 160 & .02 & .22 \\
Perception & 162 & - & .08 \\
Cumulative Chapter Activities & 162 & - & .20 \\
\hline
\end{tabular}

Table 4.17 seeks to report the relationship between a program characteristic and the influence of an advisory committee on a program. Participants reported a negligible relationship $(r=.04)$ between years teaching experience and the influence of an advisory committee. The number of teachers at a program and the influence of an advisory committee also reported a negligible relationship $(r=.02)$. Participants reported a negative negligible relationship ( $r=-.09)$ between the number of students enrolled in agricultural science and the influence of advisory committees. Programs also reported a 
negative negligible relationship ( $r=-.04)$ between the number of FFA members and the current influence of advisory committees.

Table 4.17

Influence of Advisory Committee and a Program Characteristic $(n=70)$

Influence of

Characteristic Advisory Committee $(r)$

Teaching Experience

.04

Number of Teachers

Agricultural Science Students

Current FFA Members $-.04$

The final question of the instrument asked participants to report qualitative data. Participants were asked to respond to why their program does not currently use an advisory committee. Responses $(n=71)$ were grouped into categories based on their response. Although there were 92 programs which indicated that they have no advisory committee in place, 71 participated in this section of the instrument. Table 4.18 displays qualitative responses by groups of homogeneous comments. Participants reported most commonly "not established when I got here" and "do not need an advisory committee" ( $f$ $=13,18.3 \%)$. These responses were followed by “just don't have one” $(f=9,12.6 \%)$, "would like an advisory committee, I have plans to organize" $(f=8,11.3 \%)$, "the program booster club functions as an advisory committee" $(f=7,9.8 \%)$, and "our program is too large/too small for an advisory committee to function correctly" $(f=6$, $8.5 \%)$. The least common responses were, "would like a committee, don't know how to 
organize" ( $f=4,5.6 \%)$ and "our advisory committee meets at the district level with a CTE advisory committee" $(f=4,5.6 \%)$.

Table 4.18

Qualitative Responses $(n=71)$

\begin{tabular}{lcc} 
Response Group & $f$ & $\%$ \\
\hline "Not Established When I Got Here" & 13 & 18.3 \\
"Do Not Need an Advisory Committee" & 13 & 18.3 \\
"Just Don't Have One" & 9 & 12.6 \\
"Would Like One, Plans to Organize" & 8 & 11.3 \\
"Booster Club Serves as Advisory Committee" & 7 & 9.8 \\
"Administration Doesn't Mandate" & 7 & 9.8 \\
"School Too Small/Large to Work" & 6 & 8.5 \\
"Would like to Establish, Don't Know How to Organize" & 4 & 5.6 \\
"Use District Wide CTE Committee" & 4 & 5.6 \\
\hline
\end{tabular}




\section{Chapter V}

\section{Summary, Conclusions, Implications and Recommendations}

\section{Purpose and Objectives}

The purpose of this study was to explore and describe the characteristics of advisory committees in agricultural science programs in Texas as well as examine the current and perceived influence of advisory committees on program change and development. In order to guide this study the following research objectives were developed:

1. Describe the characteristics secondary agricultural science programs which were used in this study (size of school, program, and level of competition above the local level in agricultural science or FFA activities).

2. Describe the perceived functions of advisory committee recommendations on agricultural science program change and development.

3. Describe characteristics of advisory committees used by agricultural science programs in Texas.

4. Describe the influence that advisory committees have had on program change and development.

5. Compare the perceived functions of advisory committees between programs with advisory committees and programs without advisory committees.

6. Describe the relationship between perceptions of advisory committees and a program characteristic. 


\section{Limitations}

This study focused on the use and influence of advisory committees in secondary agricultural science programs in Texas. Caution should be made when inferring the results of this study to any other state other than Texas. Caution should also be made when making conclusions on any other type of advisory committee other than those who represent Texas secondary agricultural science programs.

\section{Research Design}

This quantitative study was non-experimental and utilized a descriptivecorrelation research design. The relationships evaluated in this study were factors associated with how perceptions of advisory committees (both functions of committees and influence of current committees) relate to program and teacher characteristics. The variables that were explored included agricultural science teacher experience, number of teachers at the program, number of students enrolled in agricultural science courses, cumulative FFA student enrollment, and chapter activities above the local level. Data pertaining to program characteristics, advisory committee characteristics, perceived functions and current influence were recorded using an instrument developed by researchers at Texas Tech University.

\section{Population and Sample}

The target population of this study was secondary agricultural science programs in Texas. The accessible population was identified by a document obtained from the state association of agricultural science teachers. The document was checked for omissions and duplications before it was used. Programs $(n=278)$ were randomly selected from the document to participate in the study. An agricultural science teacher at 
each program was randomly selected to provide responses concerning advisory committees.

\section{Instrumentation}

Using zoomerang.com, a questionnaire was developed in order to obtain data to answer four pre-determined objectives from survey participants. The instrument has been classified according to question type relating to pre-determined objectives of the study. There were four sections of the instrument:

1. Influence and Characteristics of current advisory committees.

2. Agriculture Science Teacher's perceptions of advisory committees.

3. Characteristics of programs participating in the study.

4. Open-ended response section. If you do not have an advisory committee, please tell us why.

The instrument was developed specifically for this research study and questions were specific in answering pre-determined objectives. The instrument was developed to represent programs and to be answered by the agricultural science teacher who represents that program. An assurance of confidentiality in regards to participant responses was provided.

\section{Data Collection Procedures}

Data collection for this study occurred during the months of January and February 2010. This study was conducted over the course of five weeks. Data collection began on January 20, 2010 and ended on February 25, 2010. The first initial contact made with subjects $(n=287)$ contained information regarding the purpose and called for participation in the study. Following the introductory email, five additional contacts were 
made with the target population of the study asking for participation. Participants were contacted via email for all correspondence made during the course of this study.

\section{Data Analysis}

The objectives of this study were used as a guide to determine the data analysis procedures used in this research. Data was analyzed using Statistical Package for Social Sciences (SPSS) Version 17.0. Objectives in this study used frequencies, percentages, means, and standard deviations to describe and examine comparisons of the characteristics and influence of advisory committees in secondary Texas agricultural science programs. Pearson-product moment correlations were calculated to determine relationships that existed between agricultural advisory committees and a program characteristic such as size of agricultural science program and total FFA member enrollment. Independent samples $T$-tests were used to examine differences in means between programs who currently utilize advisory committees and programs who do not currently utilize advisory committees.

\section{Summary of Findings}

\section{Summary of Objective One}

Objective one sought to describe characteristics of programs which were used in this study. A total of 162 programs participated in this study. Secondary student enrollment ranged from 25-3500 with a mean of $927.55(S D=985.19)$. Of the 162 programs that participated in the study, 160 reported having students enrolled in agricultural science courses. The number of students enrolled in agricultural science classes ranged from 20-600 with a mean of $134.96(S D=134.96)$. Programs also 
reported the number of current FFA members at each program. FFA membership ranged from 5-551 and had a mean of $81.04(S D=73.85)$ members.

Programs were asked which activities above the chapter level that their FFA chapter typically participates in. The most common participation was reported in Leadership Development Events 94.4\% of participants and Career Development Events, 92\% of participants. Attendance at conventions was reported as the third most common activity with $88.9 \%$ participation. Eighty-eight point nine percent of respondents reported that their programs participate in supervised agricultural experience activities, 81.5\% reported leadership camps, and $63.6 \%$ advanced degrees. The lowest participation was reported in the areas of proficiency awards $40.1 \%$ and agriscience fair $16 \%$. From the items listed on the questionnaire, programs indicated their cumulative participation in events above the chapter level. The majority of programs indicated that they participate in seven events above the chapter level (27\%). This was followed by six events (25.9\%), five events (19.1\%), four events (10.5\%) and three events (3.1\%). Only 8.6\% of programs indicated that they participate in all eight events listed on the questionnaire.

Programs were asked to report years teaching experience for the teacher participating in the study. The mean teaching experience was 12.59 years $(S D=10.44)$. The highest frequencies of years teaching experience occurred in the lower number of years. Three years teaching experience was the highest frequency reported, followed by four years, five years, two years and one year experience. Programs indicated the number of teachers who currently teach agriculture at their school. Programs reported a mean of $1.65(S D=.785)$. The highest reported frequency was one teacher programs (51.8\%). This was followed by two teacher programs (34\%), three teacher programs 
(11.7\%) and four teacher programs (2.5\%). Almost half, $48 \%$ of programs have at least one teacher who is a member of the VATAT. This was followed by $32.7 \%$ reported having two members, and $10.5 \%$ of programs having three members. Programs also reported if their school district currently utilizes or employs a CTE director. Programs reported 53.4\% do not employ a CTE director.

\section{Summary of Objective Two}

Programs reported the agricultural science teacher's opinion toward the functions of advisory committees in agricultural science. Programs participated in this section of the questionnaire even if the program reported that they are not currently utilizing an advisory committee. Researchers in this study used a Likert-type scale to describe agricultural science teacher's feelings toward advisory committees. The Likert-scale ranged from 1-5 where $1=$ no influence, $2=$ limited influence, $3=$ some influence, $4=$ moderate influence, and $5=$ extreme influence. Programs who participated in this study believed that the most important function of an advisory committee is to act as a communication link between the community and the agriculture program $(M=3.70, S D$ $=1.04)$. Programs also reported that advisory committees had influence over the evaluation of the agricultural science program $(M=3.26, S D=1.05)$ and identifying facility modifications $(M=3.21, S D=1.05)$. Programs reported that advisory committees should have "some influence" in the areas of identifying equipment needs for the program $(M=3.16, S D=1.08)$. Agricultural science teachers who represented programs felt that advisory committees should have limited influence in the areas of hiring new instructors $(M=2.55, S D=1.14)$, reviewing instructional materials $(M=$ $2.50, S D=0.94)$, approving budgets of the program $(M=2.44, S D=1.13)$, determining 
courses to be offered to students $(M=2.75, S D=0.85)$, and approving courses to be taught to students $(M=2.61, S D=0.97)$.

\section{Summary of Objective Three}

Programs reported that $56.8 \%$ do not use advisory committees, whereas $43.2 \%$ reported that advisory committees are used. Of those who indicated having an advisory committee, $40 \%$ reported that their advisory committee is considered to be the local livestock booster club, livestock show advisory board, or parent fundraising group. Programs who reported having an advisory committee indicated that $65.7 \%$ of committees did not represent any other CTE program than agriculture. The average members on advisory committees in Texas is $6.56(S D=3.96)$. Programs reported the smallest committee being one member, and the largest committee having 20 members.

Programs who utilize an advisory committee reported characteristics regarding their agricultural science program advisory committee. Programs reported those who attend advisory committee meetings. In almost all cases, the agricultural science teacher attends advisory committee meetings $(88.6 \%)$. This was followed by parents or guardians of students $(81.4 \%)$, local industry representatives or business leaders $(77.1 \%)$, school principals (44.3\%), CTE Directors (32.9\%), school board members $(21.4 \%)$, school superintendent (20\%), student representatives (20\%), school assistant principals (15.7\%), local elected officials (8.6\%), and university professors (7.1\%).

The agricultural science teacher was reported as the most common method for preparing an agenda for an advisory committee meeting (44.3\%). Agricultural science teacher was followed by CTE Director (21.4\%), advisory committee president $(17.1 \%)$, and school administration member (11.4\%). When keeping official records of advisory 
committee proceedings, the most common method for recoding minutes was the advisory committee secretary (35.7\%). Minutes are also recorded by school administrators (17.1\%), and another member of the advisory committee (8.6\%). Of the programs surveyed, some programs indicated that they do not keep official records of meetings $(5.7 \%)$.

Most programs who participated in the questionnaire reported receiving no funding to assist in advisory committee functions (68.6\%). Of programs who do receive funding, $10.0 \%$ receive funding from fundraising efforts. Other forms of receiving funding are from the school districts general budget (8.6\%) or the chapter or program budget (2.9\%).

Programs indicated that the agricultural science teacher most commonly identifies new advisory committee members for service (70.0\%). Other ways of identifying new committee members include utilizing existing members (28.6\%), CTE Directors (18.6\%), school principals (10.0\%), and school district superintendents (5.7\%). Participants reported appointing new members for service was the most common method of selecting new members for service (70.0\%). Other ways to select members included election of new members (11.4\%) and asked to serve (10.0\%).

Programs who utilized committees reported how many members for their advisory committee have careers related to agriculture. The most common response was less than half (32.9\%), followed by the majority of members (30.0\%), half of members (17.1\%), and all members (12.9\%). The least common response was none of the members on the advisory committee have a career related to agriculture (5.7\%). 
Programs which utilize advisory committees were asked to report the frequency of meetings throughout the academic school year. The most common response was advisory committees meet once per academic semester (47.1\%), followed by meeting once per academic year (20.0\%). Other responses included meeting quarterly (15.7\%), monthly (15.7\%), and semi-monthly (1.4\%). No participants reported that their advisory committee meets weekly.

\section{Summary of Objective Four}

Objective four sought to describe influence of a program's current advisory committee. Influence was measured on a Likert-type scale where $1=$ no influence, $2=$ limited influence, $3=$ some influence, $4=$ moderate influence, and $5=$ extreme influence. Programs who utilize advisory committees believed that their advisory committee had the most influence over three areas of concentration, creating a communication link between the agricultural science program and the community $(M=3.46, S D=1.21)$, evaluating the agricultural science program $(M=3.19, S D=1.15)$, and identifying the equipment needs of the agricultural science program $(M=2.91, S D=1.09)$. Programs reported that their advisory committees have some influence on determining objectives of the program $(M=2.87, S D=1.08)$, identifying facility modifications $(M=1.83, S D=1.14)$, reviewing courses of study for accuracy and relevance $(M=2.21, S D=1.09)$, determining courses to be offered $(M=2.40, S D=0.97)$, as well as approving student courses of study ( $M=$ 2.07, $S D=1.09$ ). Programs believed that their advisory committee had limited to no influence on approving budgets $(M=2.00, S D=1.13)$, hiring new teachers $(M=1.90$, $S D=1.22)$, and reviewing instructional materials $(M=1.87, S D=0.96)$. 


\section{Summary of Objective Five}

Perceptions of the functions of advisory committees were compared to programs that currently utilize advisory committees and programs that do not utilize advisory committees. Programs who currently utilize advisory committees reported a mean function perception of $32.30(S D=7.81)$. Programs which do not utilize an advisory committee reported a mean function perception of $30.89(S D=9.02)$. Independent t-tests were analyzed. The initial hypothesis reported that there would be a statistically significant difference between perceived functions from those who indicated using an advisory committee and perceived functions from those who did not report utilizing an advisory committee. A null hypothesis indicated that there will be no significant difference. Independent t-tests revealed a t-test result of $1.04(p=.30)$. The null hypothesis was not rejected. There is no significant difference between perceived functions of advisory committees and programs who utilize advisory committees and programs that do not utilize advisory committees.

\section{Summary of Objective Six}

Objective six sought to examine the relationship between perception of advisory committees and a program characteristic such as years teaching experience, or FFA member enrollment. Perception of functions was based on the agricultural science teacher's opinion of advisory committees, whether or whether not they currently utilize one. When comparing years teaching experience of the agricultural science teacher to perceptions of advisory committees, a negative low relationship was found $(r=-.14)$. When examining the relationship between the number of agricultural science teachers at each program and perceptions of advisory committees, a negative negligible relationship 
( $r=-.11)$ was found. A negligible relationship $(r=.02)$ was reported between the number of current FFA members at each of the programs and the participant's perception of advisory committees.

This research also sought to examine the relationship between the presence of an advisory committee, and a program characteristic such as years teaching experience or a program's current FFA enrollment. A moderate relationship $(r=.44)$ was reported when years teaching experience was compared to the use of an advisory committee. When examining the number of teachers at each program compared to the current use of an advisory committee a low relationship $(r=.23)$ was reported. Researchers found a low relationship $(r=.18)$ between the number of students enrolled in each program and the current use of an advisory committee. A low relationship $(r=.22)$ was also found between the number of FFA members enrolled in each program, and the utilization of an advisory committee. The comparison between the perception of advisory committees from the views of the agricultural science teacher and the current use of advisory committees revealed a negligible relationship $(r=.08)$. When comparing chapter activity above the local level and the use of an advisory committees a low relationship $(r=.20)$ was found.

Objective six sought to examine the relationship between the influence of current advisory committees and a program characteristic such as years teaching experience or current FFA member enrollment. Influence of advisory committees is based on the agricultural science teacher's opinion of the influence of their current advisory committee. A negligible relationship to a negative negligible relationship was found 
between teaching experience, number of teachers, agricultural science student enrollment, and current FFA membership and the current influence of advisory committees.

The last section of the instrument examined qualitative data where agricultural science teachers who represented programs reported why they do not currently use an advisory committee. Responses were grouped into similar themes. The most common groups of responses were, "not established when I got here" and "do not need an advisory committee."

\section{Conclusions and Implications}

\section{Conclusions from Objective One}

1. A typical program who participated in this study had one agricultural science teacher with an average agricultural science total enrollment of 134 students and an FFA member enrollment of 81. Not all students enrolled in agricultural science courses were FFA members.

2. Programs represented high schools with an average student population of 927.55. It should be noted that the range of student population was 25-3500 with a standard deviation of 985.19 . This study surveyed programs in secondary schools of both small and large student populations. There is a vast range with regard to student enrollment.

3. The majority of schools in this study did not employ a CTE director.

4. Agricultural science teachers who represented programs in this study have a mean teaching experience of 12.59 years. The majority of teachers who participated in this study had 1-4 years of experience. The typical teacher in this study was a 
member of VATAT. These findings were similar to that of Lawver and Lee (1990).

5. Agricultural science programs who participated in this study most commonly participate in leadership development events, career development events, conventions, SAE activities, leadership camps, and advanced degrees. Programs in this study least commonly participate in proficiency awards applications and the agriscience fair.

6. Programs in Texas most commonly participate in seven of eight events listed above the local level. This finding was slightly higher than Dormody and Seevers (1994), who reported cumulative chapter participation in leadership events.

\section{Implications from Objective One}

Since FFA enrollment does not match the number of students who are enrolled in agricultural science courses, the assumption can be made that not all programs have decided to enroll in the new Texas FFA affiliation dues process ensuring where all students enrolled in agricultural science may become FFA members though one dues payment. It may depend on the individual program whether affiliation dues process may be a benefit to the program. Texas is a pilot test state for the affiliation dues process through the National FFA Organization. Many teachers in this study would be considered to be new or beginning agricultural science teachers, with experience of 1-4 years. Based on research by Burris and Keller (2008), new teachers will have low perception of how to organize and maintain an advisory committee. 


\section{Conclusions of Objective Two}

1. Overall, agricultural science teachers believe that advisory committees should have no more than "some influence" in programming and development of an agricultural science program.

2. According to the agricultural science teacher, advisory committees should have the most influence over establishing a communication link between the community and the agricultural science program $(M=3.70, S D=1.04)$, and evaluation of the agricultural science program $(M=3.26, S D=1.05)$. The opinion of agricultural science teachers falls in line with advisory committee development resource materials. The University of Missouri- IML (1997) found that creating public awareness of the advisory committee can increase knowledge of the program. This finding was similar to the National FFA Organization's (1998) statement that an advisory committee will evaluate a current agricultural science program to determine if it is providing career training and preparation for students.

3. Agricultural science teachers believe that advisory committees should have no influence in hiring new teachers or reviewing instructional materials for the program. These findings are a direct contradiction to what Talbert, Vincent, Croom, and Lee (1998) recommend specifically as functions of advisory committees.

\section{Implications from Objective Two}

Overall, agricultural science teachers who represent programs in this study do not believe their advisory committees should have more than "some influence" over a set of 
variables related to program development and implementation. Teachers could have this opinion based on lack of education or lack of utilization of a committee. Since this objective surveys both teachers who utilize advisory committees and those that do not, many teachers who responded to the instrument for this study may have never implemented an advisory committee. Therefore, teachers may not know what a committee can do for their program. Programs should use reference materials to help the agricultural science teacher establish and maintain an advisory committee.

\section{Conclusions from Objective Three}

1. More than half of the programs in Texas do not utilize an agricultural science advisory committee (56.8\%). This finding was significantly higher than a previous study conducted in California. Whaley and Sutphin (1987) reported that $22 \%$ of California programs did not utilize and advisory committee. This finding is extraordinarily lower than Dormody, Seevers, \& Clason (1996) reported.

2. Many (40\%) programs who utilize an advisory committee, use their advisory committee also as a livestock show board, parent fundraising group, or booster club.

3. A typical program in Texas has an advisory committee that does not serve other CTE programs. Whaley and Sutphin (1987) found that $8.6 \%$ of programs in California utilized the program advisory committee for another CTE program other than agriculture.

4. Most commonly, advisory committee meetings in Texas are attended by the agricultural science teacher (88.6\%), parents or guardians of students $(81.4 \%)$, and local industry or business representatives (77.1\%). 
5. Overall, advisory committees in Texas keep official minutes of advisory committee proceedings (94.3\%). Minutes are most commonly kept by the agricultural science teacher (44.3\%), followed by the advisory committee secretary $(35.7 \%)$. The agricultural science teacher is the most common method for preparing an agenda for a committee meeting (44.3\%).

6. The normal advisory committee in Texas does not receive any funding for conducting official business (68.6\%), and less than half of the members on the advisory committee have a career related to agriculture (32.9\%). Advisory committees in Texas most regularly meet once per academic semester (47.1\%). It could be inferred that typical advisory committees in Texas do not participate in activities where funding is necessary.

7. Generally, advisory committees in Texas have three (11.4\%) to eight $(5.7 \%)$ members with a most common membership of five members (25.7\%). This finding was similar to that of Whaley and Sutphin (1987) which found that a majority of advisory committees had memberships of five through ten members.

\section{Implications from Objective Three}

Texas as a whole does not utilize advisory committees, and therefore is out of compliance with Texas CTE standards (Texas Education Agency, 2007). The current use of advisory committees could represent a lack of understanding toward the advisory committee development process by agricultural science teachers. These findings could also represent a lack of knowledge by beginning teachers to develop and manage an advisory committee as found in literature. Advisory committees could lack priority or importance in the hectic schedule of an agricultural science teacher. After 23 years, 
findings in Texas are generally very similar to that of a California study with many of the same objectives presenting similar views toward advisory committees.

\section{Conclusions from Objective Four}

1. When measuring their current advisory committees, agricultural science teachers who represented programs in this study reported no more than "some influence" over programming and development of an agricultural science program. This is consistent with the findings from Whaley and Sutphin (1987) findings regarding the influence of agricultural science advisory committees.

2. Currently, agricultural science teachers believe that their advisory committees have the most influence over creating a communication link between the program and the community $(M=3.46, S D=1.21)$, and evaluating the agricultural science $\operatorname{program}(M=3.19, S D=1.15)$.

3. Teachers believe that their advisory committee have no influence on approving budgets for the program $(M=2.00, S D=1.13)$ hiring new teachers for the program $(M=1.90, S D=1.22)$ and reviewing instructional materials for teaching $(M=1.87, S D=0.96)$.

\section{Implications from Objective Four}

Overall, programs who utilize advisory committees did not believe their advisory committee had more than "some influence" in any objectives of an advisory committee. One reason for this low number of influence could be that teachers do not want to release any more duties to their advisory committee, or are not currently utilizing all suggestions that are made by their advisory committee. Another reason for this low number could be 
that the administration for a school could limit the amount of influence the advisory committee has over the program.

\section{Conclusions from Objective Five}

1. There is not a statistically significant difference of perception of functions between those who utilize advisory committees and those who do not utilize advisory committees.

\section{Implications from Objective Five}

While no statistically significant difference was indicated in perceptions of functions of committees between those who utilize advisory committees and those who do not utilize advisory committees, there was an actual difference found.

\section{Conclusions from Objective Six}

1. There is a low negligible relationship $(r=-.14)$ between years teaching experience and the teacher's opinion of the usefulness advisory committees.

2. There is a low relationship between the number of teachers at a program and the teacher's opinion of the usefulness of advisory committees $(r=-.11)$ as well as the current enrollment of FFA members at each program and the opinions of the agricultural science teacher $(r=.02)$.

3. There is a moderate relationship $(r=.44)$ between years teaching experience and the presence of an advisory committee in a program.

4. There is a low relationship between the number of teachers at each program $(r$ $=.23)$, number of students enrolled in agricultural science courses $(r=.18)$, the number of current FFA members $(r=.22)$, chapter activities above the local level $(r=.08)$ and the current use of an advisory program. 
5. There is a negligible relationship between influence of current advisory committees and years teaching experience $(r=.04)$, number of teachers $(r=$ $.02)$, student enrollment $(r=-.09)$, and FFA membership $(r=-.04)$.

6. Agricultural science teachers indicated that the most common reason that they do not have an advisory committee in place is because there was "not one in place when I got here".

\section{Implications from Objective Six}

There does not seem to be any substantial relationship between advisory committees and variables such as years teaching experience, number of students enrolled in agricultural science courses or the number of FFA members. A moderate relationship exists between years teaching experience and the utilization of an advisory committee by the program. An explanation of this could be that as agricultural science teachers gain more experience teaching, other areas of teaching become less stressful and allow time to plan and manage an advisory committee. Also, teachers who have more experience teaching could see benefits in using an advisory committee for the benefit of their program. The largest response from teachers concerning why they do not have an advisory committee is "not one here when I got here". One could infer that teachers do not have a clear enough understanding of advisory committees to know how to establish and manage a committee. Also, teachers may not understand the benefits of having a committee enough to spend time and effort to establish one. This response from teachers could also show that teachers place very little importance in an advisory committee. 


\section{Recommendations}

\section{Recommendations for Practice}

1. The top two functions of advisory committees should be to create a communications link between the agricultural science program and the community and to evaluate the program to see if the program meets the needs of the community.

2. Based on the findings of this study, managerial practices for advisory committees should include: advisory committee chairman and agricultural science teacher work together to develop an agenda, an accurate set of minutes should be kept of meeting proceedings, advisory committees should include industry and business leaders as well as administrators and parents.

3. University agricultural science teacher preparation programs should continue to emphasize the importance of establishing an advisory committee and supply students with well developed curriculum to help the students achieve this goal.

4. Advisory committees should be established and managed for all secondary agricultural science programs in Texas. Advisory committees can be effective regardless of size of program, number of agricultural science teachers or years teaching experience.

5. Based on the lack of knowledge from agricultural science teachers regarding the use of an advisory committee, a professional development workshop should be planned and implemented in order to educate current teachers on the findings of this study as well as provide ideas for establishing a committee. Current teachers who utilize advisory committees should be asked to present and share advisory 
committee success stories to educate teachers on ways advisory committees have helped them.

6. It is a recommendation of this study that any state mandated efforts to systematically enforce the use of advisory committees should consider the diversity of the agricultural science programs in that state.

7. The State of Texas should provide current CTE programs with a model or guidelines in order to assist programs in the establishment and implementation of advisory committees.

\section{Recommendations for Research}

1. This study examined factors associated with agricultural science teacher's opinions regarding the usefulness of their current advisory committee and what an advisory committee functions should be. Further research should be conducted to examine school administrator's opinions of advisory committees on factors pertaining to program implementation and development.

2. Agricultural science teachers rated the perceived functions of advisory committees and the influence that their committee has on program development. Further studies should be conducted to examine advisory committee's opinions of their own perceived functions in the agriculture program.

3. Further investigation should be conducted to determine where programs who do not currently utilize an advisory committee are receiving program planning advice if that advice is not coming directly from an advisory committee.

4. Further research should be conducted to examine why programs do not utilize advisory committees to assist in program planning and implementation. A 
qualitative study could be conducted to examine agricultural science teacher's thoughts concerning their nonuse of an advisory committee.

5. This study found that statistically there was no significant difference between perceptions of advisory committees between those who use committees and those who do not. Further research is needed to determine if there is a practical difference between programs who utilize advisory committees and programs that do not utilize advisory committees. 


\section{References}

Ary, D., Jacobs, L.C., \& Razavieh, A. (2002). Introduction to research in education ( $6^{\text {th }}$ ed.). Belmont, Ca: Wadsworth/Thompson Learning.

Barnett, J., Johnson, E. \& Verma, S. (1999). Effectiveness of cotton advisory committees. Journal of Extension. 37(6). Retrieved from http://www.joe.org/joe/ 1999december/a5.php

Black, D.C., Howe, G.W., Howell, D.L., and Bedker P. (1992). Selecting advisory council members. Journal of Extension. 30(1). Retrieved from http://www.joe.org/joe/1992spring/a4.php

Boone, E.J., Safrit, R.D., \& Jones, J. (2002). Developing Programs in Adult Education. Long Grove, Il.: Waveland Press.

Boyle, P.G. (1981). Planning better programs. New York, New York: McGraw-Hill.

Burris, S. \& Keller, J. (2008). Professional roles and responsibilities: challenges for induction teachers. Journal of Agricultural Education, 49, 123-127. doi: $10.5032 / \mathrm{jae} .2008 .02118$

Carl. D. Perkins Career and Technical Education Act of 2006, Pub. L. 105-220, 1, Stat. 250-251 (2006).

Davis, J.A. (1971). Elementary survey analysis. Englewood, NJ: Prentice-Hall.

Dillman, D.A. (2007). Mail and internet surveys: the tailored design method $\left(2^{\text {nd }}\right.$ ed.). Hoboken, NJ: John Wiley \& Sons, Inc.

Dormody, T.J.\& Seevers, B.S. (1994). Participation of FFA members in leadership development activities: a tri-state study. Journal of Agricultural Education, 35(4) 42-48. Retrieved from http://pubs.aged.tamu.edu/jae/pdf/Vol35/35-04-42.pdf

Dormody, T.J., Seevers, B.S. \& Clason, D.L. (1996). Teacher perceptions of the goals achieved by adult organizations in agricultural education. Journal of Agricultural Education, 37(1), 31-40. Retrieved from http://pubs.aged.tamu.edu /jae//pdf/vol37/37-01-31.pdf

Ebling, S.K. (1985). Using advisory committees effectively. Journal of Extension. 23(3). Retrieved from http://www.joe.org/joe/1985fall/siw2.php

Education Amendments of 1976, Pub. L. No. 94-482, (1976). 
Gall, M.D., Gall, J.P., \& Borg, W.R. (2007). Educational research ( $8^{\text {th }}$ ed.). Boston, Ma: Pearson Publishing.

Hayward, G.C. \& Benson, C.S. U.S. Department of Education, Office of Vocational and Adult Education. (1993). Vocational-technical education: major reforms and debates 1917-present. Retrieved from http://eric.ed.gov/ERICWebPortal/custom/portlets/ recordDetails/detailmini.jsp?_nfpb=true\&_\&ERICExtSearch_SearchValue_0=ED 369959\&ERICExtSearch_SearchType_0=no\&accno=ED369959

Instructional Materials Laboratory. (1997). Partnerships and advisory groups. Columbia, Mo.: University of Missouri.

Krejcie, R.V. \& Morgan, D.W. (1970). Determining sample size for research activities. Educational and Psychological Measurement, 30, 607-610

Lawver, D.E. \& Lee, J.S. (1990) Comparison of members and non-members of professional organizations for vocational agriculture teachers. Journal of Agricultural Education, 31(4), 39-45. Retrieved from http://pubs.aged.tamu.edu/jae/pdf/Vol31/31-04-39.pdf

Layfield, K.D. \& Dobbins, T.R. (2002). Inservice needs and perceived competencies of South Carolina agricultural educators. Journal of Agricultural Education, 43(4), 46-55. Retrieved from http://pubs.aged.tamu.edu/jae/pdf/Vol43/43-04-46.pdf

Linder, J.R., Murphy, T.H., \& Briers, G.E. (2001) Handling nonresponse in social science research. Journal of Agricultural Education, 42(4), 43-52.

Myers, B.E. Dyer, J.E. \& Washburn, S.G. (2005) Problems facing beginning agriculture educators. Journal of Agricultural Education, 46(3), 47-55. Retrieved from http://plaza.ufl.edu/bmyers/Papers/SAERC2004/ProblemsBeginningTeachers.pdf

National FFA Organization. (1998). A guide to local program success. Indianapolis, In.: National FFA Organization.

National FFA Organization. (2010). Official FFA manual. Indianapolis, In: National FFA Organization

Nunnally, J.C. (1967). Psychometric Theory. NY: McGraw Hill Book Company, Inc.

Pawlak, E.J. \& Vinter, R.D. (2004). Designing and Planning Programs. San Francisco, Ca.: Jossey-Bass. 
Phipps, L.J., Edward, E.W., Dyer, J.E., Ball, A. (2008). Using Advisory Councils and Support. Handbook on Agricultural Education in Public Schools (81-93). Clifton Park, NY: Thompson Delmar Learning

Place, N.T., (2007). Using nominal group techniques for helping new extension agents understand how to effectively involve advisory committee members. Journal of Extension. 45(1). Retrieved from http://www.joe.org/joe/2007february/index.php

Talbert, B.A., Vaughn, R., Croom, D.B. (2005). Advisory and Citizen Groups. Foundations of Agricultural Education (121-140). Danville, IL: Professional Educators Publications, Inc.

Talbert, B.A., Vaughn, R., Croom, D.B., Lee, J.S. (2007). Advisory and Citizen Groups. ( $2^{\text {nd }}$ Eds.), Foundations of Agricultural Education (121-140). Danville, IL: Professional Educators Publications.

Texas Essential Knowledge and Skills for Career and Technical Education, Subchapter A. Agriculture, Food and Natural Resources. (2010). Retrieved from http://ritter.tea.state.tx.us/rules/board/adopted/0709/ch130a-two.pdf

Texas State Plan for Career and Technical Education 2008-2013 (2007). Retrieved from http://ritter.tea.state.tx.us/cte/Accountability/StatePlanFinal111607.pdf

University of Georgia. (N.D.). A handbook for the creation and operation of an agriculture education advisory committee. Athens, Ga.: Department of Agricultural Education.

Vocational Education Act of 1963, H.R. 4955, 88 Cong. (1963).

Wegenhoft, A.A., Holt, B.A. (1988). Who's doing the work? Journal of Extension. 26(2). Retrieved from http://www.joe.org/joe/1988summer/a4.php

Whaley, D.C., \& Sutphin, H.D. (1987). The status and influence of agricultural advisory committees in California. Journal of Agricultural Education, 28(3), 37-42, 48. Retrieved from http://pubs.aged.tamu.edu/jae//pdf/vol28/28-03-37.pdf

Young, G. (2010, February 10) Re: Legislative Update. Retrieved from http://www.vatat.org/TeacherToolbox/LegislativeUpdate.aspx 
Texas Tech University, Joseph C. Barbour, August 2010

\section{Appendix A}

\section{Instructional Review Board Approval}


January 26,2010

Dr. Scott Burris

Ag Ed \& Communications

Mail Stop: 2131

Regarding: 502217 Characteristics and Influence of Advisory Committees on Program Planning in Secondary Agricultural Programs in Texas

Dr. Scott Burris:

The Texas Tech University Protection of Human Subjects Committee approved your claim for an exemption for the proposal referenced above on January 19, 2010.

Exempt research is not subject to continuing review. However, any modifications that (a) change the research in a substantial way, (b) might change the basis for exemption, or (c) might introduce any additional risk to subjects must be reported to the IRB before they are implemented.

To report such changes, you must send a new claim for exemption or a proposal for expedited or full board review to the IRB. Extension of exempt status for exempt projects that have not changed is automatic.

The IRB will send annual reminders that ask you to update the status of your research project. Once you have completed your research, you must inform the Coordinator of the Committee either by responding to the annual reminder or by notifying the Coordinator by memo or e-mail (donna.peters@ttu.edu) so that the file for your project can be closed.

Sincerelv.

Rosemary Cogan, Ph.D., ABPP

Protection of Human Subjects Committee 
Texas Tech University, Joseph C. Barbour, August 2010

Appendix B

Instrumentation 
The questionnaire that you are about to complete involves research conducted by: Dr. Scott Burris and Joe Barbour

Texas Tech University

Department of Agricultural Education and Communications

(806) $742-2816$

Box 42131

Lubbock, Texas 79409

This survey will take approximately 15 minutes. Please answer each question regarding advisory committees before moving on to the next page. When you are finished with the survey, please submit.

There are no foreseeable risks associated with this questionnaire, and there are no benefits associated with participation. Your responses to this questionnaire will be considered confidential. Participation is this study is voluntary and subjects participating or who refuse to participate will receive no penalty or benefits. Participants may discontinue participation at any time without penalty. Results of this study will be available at the conclusion by contacting Dr. Scott Burris or Joe Barbour. Dr. Burris will answer any questions you have about the study. For questions about your rights as a subject or about injuries caused by this research, contact the Texas Tech University Institutional Review Board for the Protection of Human Subjects, Office of Research Services, Texas Tech University, Lubbock, Texas 79409. Or you can call (806) 742-3884. 


\section{Characteristics and Influence of Advisory Committees}

Page 1 - Cuestion 1 - Open Ended - One Line

Please enter your Chapter number? This question will only be used to identify you so that you may be taken off the mailing list after completing the questionnaire.

Page 2 - Question 2 - Choice - One Answer (Bullets) [Mandatory

Do you have an advisory committee? If you answer no, please select submit at the bottom of the page which will move you to section 2 .
Yes
No [Skip to 8]

Page 3-Heading

Section 1- Page 1 of 5

This section is designed to measure the influence of your current advisory committee.

Page 3 - Cuestion 3 - Rating Scale - Mattix

How influential has your advisory committee been in making the following decisions?

Determining courses to be offered

Determining the objectives of the agrioultural program

Hiring new instructors or teachers

No Infulence Uimited Infnuence

Some infuence

Woderatg Intuence Extreme inhuence

Approval of working, travel, or other budget funds

Approving courses of study Reviewing courses of study for content relevance and accuracy Idertifing the equipmert, boos, and supplies needed for the program Identifying facility modifications needed Reviewing instructional materials

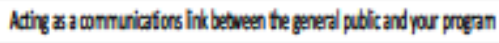
Evaluating the agricultural program

0

O

○

○

0

0

O

O

O

○

O
O

O

O

O

0

O

O

O

O

O

○
O

O

○

○

O

○

○

○

○

○

O
○

O

O

0

0

O

0

○

0

O

O
O

O

○

0

0

○

O

O

O

O

O

Paqe 4-Heading

Section 1-Page 2 of 5

Page 4 - Cuestion 4 - Cholce - One Answer (Drop Down)

How many members serve on your advisory committee?
(1) 1
( 2
O 3
(1) 4
(1) 5
6
( 7
( 8
○ 9
( 10
() 11 
$\begin{array}{ll}\bigcirc & 12 \\ 0 & 13 \\ 0 & 14 \\ 0 & 15 \\ 0 & 16 \\ 0 & 17 \\ 0 & 18 \\ 0 & 19 \\ 0 & 20\end{array}$

Page 4- Question 5 - Yes or No

Are the people on your advisory committee also considered your livestock booster club, parent support group, livestock show board or fundraising group?

Yes

No

Additional Comment

Page 4 - Cuestion 6 - Cholce - One Answer (Bullets)

How often does your advisory committee conduct official meetings?
weekly
semi-monthly
monthly
quarterly
once per academic semester
once per academic year

Page 4-Cuestion 7 - Choice - One Answer (Bullets)

Does your advisory committee represent another Career and Technical Education (CTE) program in addition to agriculture?

Yes

No

Page 5 - Heading

Section 1- Page 3 of 5

Page 5 - Question 8 - Cholce - Multiple Answers (Bullets)

Who attends your advisory committee meetings? Please check all that apply.

$\square$ Agricultural Science Teachers

$\square$ Local Business or Industry Representatives (who are not parents of current ag students)

$\square$ Parents or Guardians

$\square$ School Principal

$\square$ School Assistant Principal

$\square$ School Superintendent

$\square$ School Board Members

$\square$ Career and Technology Directors

$\square$ University Professors

$\square$ Student Representatives

$\square$ Local Elected Officials 
Other, please specify

Page 5 - Cuestion 9 - Choice - One Answer (Bullets)

Who prepares the agenda for the advisory committee meeting?

Advisory committee president

Advisory committee secretary

Other advisory committee member

Agricultural Science Instructor

School administration member

Career and Technology Director

0 Other, please specify

Page 5 - Cuestion 10 - Choice - One Answer (Bullets)

Does your advisory committee receive funds to conduct activities? If so, where do your funds come from?

Our school district provides funding through general budget

Advisory committee is funded through chapter/program budget

Advisory committee is provided funding through fundraiser efforts

Our program advisory committee does not receive any funds

Other, please specify

Page 6 - Heading

Section 1- Page 4 of 5

Page 6-Cuestion 11 - Cholce - One Answer (Bullets)

Who is in charge of official minutes for the advisory committee?

A secretary on our committee keeps minutes

Other member of our committee keeps minutes

- Agricultural Science instructor records minutes

School administrator records minutes

Our committee keeps no records of meeting proceedings

$O$ Other, please specify

Page 6 - Cuestion 12 - Cholce - Muttple Answers (Bullets)

Who identifies new comittee members for service on the advisory committee?

- Ag teacher

Existing committee members

$\square$ School board members

$\square$ Principal

$\square$ Superintendent

$\square$ CTE Director

$\square$ Other, please specify 
Page 6 - Cuestion 13 - Cholce - One Answer (Bullets)

How are new advisory committee members selected?

Elected

Appointed

Other, please specify

Page 7 - Headlng

Section 1- Page 5 of 5

Page 7 - Question 14 - Cholce - One Answer (Bullets)

How many members on your committee have careers related to agriculture?

All Members

Majority of the Members

Half of the Members

Less than half of the Members

None of the Members

Page 7 - Question 15 - Cholce - Muttiple Answers (Bullets)

Who from your school administration attends your advisory committee meeting?

$\square$ School Principal

$\square$ School Assistant Principal

$\square$ School Superintendent

- School Assistant Superintendent

$\square$ CTE or Vocational Director

$\square$ My school administration does not attend our meetings

$\square$ Other, please specify

Page 8 - Headling

Section 2- Page 1 of 1

This section is designed to measure your perceptions of what an advisory committee should be.

Page 8 - Question 16 - Rating Scale - Matrtx

How much influence do you think an advisory committee should have in making the following decisions?

Determining courses to be offered Determining the objectives of the agrioultural program Hiring new instructors or teachers Approval of working, travel, or other budget funds

Approving courses of study Reviewing courses of study for content relevance and accuracy Idertifing the equipmert, bols, and supplies needed for the program Identifying facility modifications needed Reviewing instructional materials Ating $x$ a mnruricaitors in bebveen the general puticand por progan Evaluating the agricultural program

No Inf

No Infulence

Umithed Innuence

0

0

0

0

0

O

O

O

O

O
0

0

O

O

O

O

O

O

O

O

O
Some influence

0

O

O

O

O

○

O

O

O

O

○
Uoderatg intuence

O

0

0

O

O

O

O

O

O

○

○
?

O

O

O

O

O

O

O

O

○ 
Texas Tech University, Joseph C. Barbour, August 2010

Page 9-Heading

Section 3- Page 1 of 2

Page 9 - Question 17 - Cholce - One Answer (Drop Down)

How many years have you taught agriculture (including the current year)?

1 (first year)

() 2

(1) 3

(1) 4

() 5

(.) 6

O 7

( 8

( 9

() 10

() 11

() 12

() 13

() 14

() 15

() 16

() 17

() 18

() 19

( 20

() 21

() 22

() 23

() 24

() 25

() 26

() 27

() 28

() 29

() 30

(.) 31

() 32

33

() 34

() 35

( 36

37

38

39

40

41

42

43

O 44

( ) $45+$ 
Page 9 - Cuestion 18 - Cholce - One Answer (Drop Down)

Please select the number of agricultural science instructors who teach agriculture at your school (including yourself).

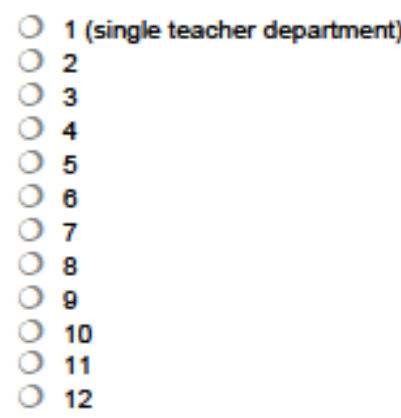

Page 9 - Question 19 - Cholce - One Answer (Drop Down)

How many teachers at your school are currently members of the Vocational Agricultural Teachers Association of Texas?
0
( 1
O 2
( 3
O 4
○ 5
() 6
○ 7
( 8
( 9
() 10
() 11
○ 12

Page 9 - Cuestion 20 - Choice - One Answer (Bullets)

Does your school district currently employ a CTE Director or Vocational Director?

Yes

No

Page 10 - Heading

Section 3- Page 2 of 2

Page 10 - Question 21 - Open Ended - One Une

Please give the total enrollment size of your high school. Please indicate numerically.

Page 10 - Question 22 - Open Ended - One Une

Please select the number of students enrolled in agricultural science classes at your school (no duplicates from class to class). Please indicate numerically. 
Page 10 - Question 23 - Open Ended - One Une

Please select the total enrollment of FFA members in your chapter (no duplicates). Please indicate numerically.

Page 10 - Question 24 - Choice - Multiple Answers (Bullets)

Please select the activities above the chapter level that your FFA chapter typically participates in. Select all that apply.

$\square$ Leadership Development Events

$\square$ Career Development Events

$\square$ Supervised Agricultural Experience Activities

$\square$ AgriScience Fair

$\square$ Advanced Degrees

$\square$ Conventions

Leadership Camps

Proficiency Award Programs

Page 11 - Heading

Section 4- Page 1 of 1

Page 11 - Question 25 - Open Ended - Comments Box

If you do not use an advisory committee, please tell us why. 